\title{
DESIGN AND PROPERTIES OF ECO-FRIENDLY BINARY MORTARS CONTAINING ASH FROM BIOMASS-FUELLED POWER PLANTS
}

\author{
J.M. Medina ${ }^{1 *}$, I.F. Sáez del Bosque ${ }^{1}$, M. Frías², M.I. Sánchez de Rojas², C. Medina ${ }^{1 *}$ \\ 1. Department of Construction, School of Engineering, University of Extremadura, UEx-CSIC \\ Partnering Unit, Institute for Sustainable Regional Development (INTERRA), 10003 - Cáceres, \\ Spain \\ 2. Materials Recycling Department, Eduardo Torroja Institute for Construction Science, Spanish \\ National Research Council (CSIC), 28033 - Madrid, Spain \\ Corresponding authors: *ingepisuerga@gmail.com \\ *comedinam@unex.es / cemedmart@yahoo.es
}

\begin{abstract}
The use of biomass to produce electric power and heat will intensify in the years to come, in pursuit of sustainable growth. Stockpiling the vast amounts of fly and bottom ash generated in that process wastes resources and has an adverse impact on the environment.

The viability of bottom ash as a supplementary cementitious material in new eco-efficient cements is studied, including its effect on binder chemical, rheological, mechanical and microstructural properties. The findings show that these additions induce improvements in later age mechanical performance relative to conventional mortars. An ANOVA conducted to determine the impact of waste type, replacement ratio and curing time on compressive and flexural strength reveals that the latter two have a significant effect on mechanical properties. The new cements meet the requirements laid down in EN 197-1 for CEM II/A and CEM IV/A cements, making them apt for use in construction.
\end{abstract}

Keywords: biomass ash, blended cement, strength development, supplementary cementitious materials, porosity

\section{Introduction}

Portland cement is the binder most widely used in construction. Cement is manufactured with raw materials such as ground and blended limestone $\left(\mathrm{CaCO}_{3}, 80 \%\right)$ and clays $\left(\mathrm{SiO}_{2}, \mathrm{Al}_{2} \mathrm{O}_{3}\right.$ and $\mathrm{Fe}_{2} \mathrm{O}_{3}$, 20\%) [1]. The mix is subsequently burnt at a temperature of $\sim 1450{ }^{\circ} \mathrm{C}$ to form the clinker phases alite, belite, tricalcium aluminate and ferrite. In CEM I portland cement, the cooled clinker is then ground and mixed with $\sim 5 \%$ gypsum, which acts as a setting regulator. The vast volumes of GHGs belched by cement plants due to limestone and fossil fuel decarbonation account for $5 \%$ to $7 \%$ of worldwide $\mathrm{CO}_{2}$, the primary cause of global warming [2].The industry is also raw material- and 
energy-intensive: $1 \mathrm{t}$ of clinker is estimated to require $1.7 \mathrm{t}$ of raw materials and $3.2 \mathrm{GJ}$ to $6.3 \mathrm{GJ}$ of energy [3].

With a view to reducing both noxious effects of cement manufacture, clinker is often partially replaced by amorphous silica-high waste with fine particle sizes such as fly ash and blast furnace slag, the use of which is regulated in EN 197-1 [4].

In conjunction with those measures, a number of legislative provisions are in place to further environmentally sustainable policies. More specifically, European Directive 2009/27/EC [5] and Spain's renewable energy plan PER 2011-2020 [6] prescribe measures to foster renewable energy use, energy savings and energy efficiency. The target is for renewables to constitute a $20 \%$ share of the total energy consumed in 2020 [5]. Compliance with such policies should reasonably lead to an increase in biomass-fuelled electric power and heat generation in the years to come. The combustion of forestry, woody and non-woody plant (corn, oil, seed, sugar cane, wheat) biomass generates vast amounts of ash that are presently stockpiled in spoil heaps.

The two types of such ash are: biomass fly ash, BFA, generated during combustion and escaping into chimneys [7] where it is retained by cyclones, precipitators or baghouse filters to prevent release into the atmosphere [8, 9]; and biomass bottom ash, BBA, also known as slag, which is the noncombustible waste remaining in furnaces or incinerators [7] that is removed from the combustion chamber $[8,10]$. As a rule BFA has a smaller particle size than BBA [11].

Recent research has addressed the use of ash from laboratory-combusted agro-industrial waste (such as sugar cane [12, 13], bamboo leaves [14-16], rice husk [17, 18] and elephant grass [19]) as supplementary cementitious materials (SCMs). Very few studies have been conducted, however, on the use in construction of biomass waste from large-scale combustion of a variety of agroindustrial by-products at power and heat plants, and the results have been inconclusive. Most of those studies focus on biomass fly ash (BFA), and very few on biomass bottom ash (BBA).

The first group studies have dealt, for instance, with applying olive grove or pine forest pruning [11] or olive milling [20] combustion ash to manufacture brick. Woody biomass has been used as a natural filler in self-consolidating concretes (for a priori this waste exhibits pozzolanicity too low for direct inclusion as a cement addition, with a low $\mathrm{SiO}_{2}+\mathrm{Al}_{2} \mathrm{O}_{3}+\mathrm{Fe}_{2} \mathrm{O}_{3}$ and a high $\mathrm{CaO}$ content $\left.[7,21]\right)$ or as an addition in concrete design, in research showing that at replacement ratios of under $25 \%$ mechanical performance remained unaltered and at over $25 \%$ declined after $28 \mathrm{~d}$ [22]. It has also 
been used as a cement replacement, i.e., a supplementary cementitious material (SCM) in mortar and cement manufacture.

Rajamma et al. [23, 24] analysed mortar containing $10 \%, 20 \%$ or $30 \%$ forest waste combustion BFA at a power plant in Portugal, observing that at over $20 \%$ mechanical performance declined substantially, whereas at $10 \%$ it was comparable to that of OPC. A similar line of research (Horsakulthai et al. [25]) studied the viability of BFA from the combustion of $82.5 \%$ bagasse, $15 \%$ rice husk and $2.5 \%$ chopped wood at a small steam power plant supplying electricity for sugar mills. When they replaced $10 \%$ and $20 \%$ of the cement to manufacture concrete they found that the new concretes exhibited compressive strength slightly higher than the control and high resistance to chloride penetration and corrosion, i.e., good durability. Jidrada et al. [26] analysed the viability of valorising rice husk and eucalyptus combustion ash ground to different particle sizes as SCMs at replacement ratios of $15 \%$ to $45 \%$. They observed that the inclusion of the ash raised water demand and lowered mechanical strength, more intensely at higher ratios. Ramos et al. [27], researching the use of $10 \%$ and $20 \%$ fly ash from wood combustion at a power plant as an SCM, observed that at later ages mechanical strength in the experimental and reference cements was similar. Another study in this group conducted by Gan and Ramli [28] using woody biomass ash as an SCM at 10\%, $20 \%$ or $30 \%$ found mechanical performance to rise at $10 \%$ and to decline at the higher percentages. At this writing, the short number of papers published on BBA valorisation can be divided into three classes, depending on the use: as SCMs or fillers in mortars; as sand in mortar design [29] or granular material in structural layers for roads [30, 31]; and as a raw material in brick manufacture [32].

The first group includes research conducted by Rosales et al. [33] in which olive waste combustion BBA ( $40 \%$ olive cake and $60 \%$ woody biomass from poplar, olive and pine trees) was used to replace cement at $20 \mathrm{wt} \%$ and $38.5 \mathrm{vol} \%$ with a decline in mechanical performance. In contrast, García et al. [34] observed higher $28 \mathrm{~d}$ compressive strength in standardised mortars containing $5 \%$ or $10 \%$ woody or forestry biomass and lower strength in earlier age materials. Sklivaniti et al. [35], using olive pruning combustion bottom ash as a filler, observed $20 \%$ to $30 \%$ declines in compressive strength at $2 \%$ to $10 \%$ replacement ratios.

BBA valorisation is, then, an innovative line of research for a number of reasons. Very little has been published on the use of BBA in new cement design. No references are found in the literature on the 
valorisation of simultaneous woody and non-woody plant combustion ash. The reuse of this material has not been addressed in the legislation, while its volume is increasing yearly due to the rise in the number of biomass-fuelled power plants. Scientific understanding of the mechanical behaviour and microstructure of these new materials is consequently needed.

This study attempts to fill the existing scientific-technical lacunae on the viability of using BBA in civil and building construction. It assesses the effect of replacing cement with $10 \%$ or $20 \%$ BBA from three Spanish power plants on the chemical, rheological, mechanical and microstructural properties of the new sustainable binders, comparable to II/A and IV/A cements. A univariate analysis of variance (ANOVA) is run to assess the impact of age, replacement ratio and BBA type (factors) on compressive and flexural strength (dependent variables).

\section{Materials and procedures}

\subsection{Materials}

Three types of BBA were sourced from three non-woody (straw, rye, oats, corn...) and woody (pine, eucalyptus, fruit tree) biomass-fuelled power plants in Spain [36], labelled S1, S2 and S3. A ternary diagram (Vassilev et al. [21, 37, 38]) drawn from the XRF chemical composition, determined previously [36], showed the biomass waste to be type S, sub-type MA (see Figure 1). The silica content in all three was over the $25 \%$ minimum required in EN 197-1 [4] to qualify as a pozzolanic material. The silica content in the three types of waste was, in decreasing order: S1>S2>S3 [36].

Figure 1. Position of three types of biomass waste on the ternary diagram proposed by Vassiliev et al. $[21,37,38]$ for the chemical classification of the inorganic matter in biomass ash The chemical composition of the ordinary CEM I 42.5R cement used, supplied by Lafarge, a cement manufacturer sited in the Spanish province of Toledo, included: $\mathrm{CaO}(62.05 \%), \mathrm{SiO}_{2}(18.71 \%)$, $\mathrm{Fe}_{2} \mathrm{O}_{3}(2.53 \%), \mathrm{Al}_{2} \mathrm{O}_{3}(4.29 \%)$, and small amounts of $\mathrm{MgO}(1.95 \%)$, alkalis $\left(\mathrm{Na}_{2} \mathrm{O}_{\text {equivalente }}=0.63 \%\right)$ and $\mathrm{SO}_{3}(3.23 \%)$.

The mortars were prepared with CEN-standardised EN 196-1 [39] -compliant sand with a particle size ranging from $2.0 \mathrm{~mm}$ to $0.078 \mathrm{~mm}$.

\subsection{Methods}

\subsubsection{Frattini test}


Pozzolanicity was determined with the Frattini test described in EN 196-5 [40]. That test determines the $8 \mathrm{~d}$ and $15 \mathrm{~d}$ calcium ion concentration in the aqueous solution present in the cements studied (10\% biomass waste/90\% OPC and $20 \%$ biomass waste/80\% OPC).

\subsubsection{Setting and slump test}

The initial and final setting times for the new blended cements were determined using a Vicat needle as described in EN 196-3 [41]. Cement soundness in normal consistency cement paste was studied with a Le Chatelier instrument as specified in the aforementioned standard.

\subsubsection{Mechanical properties}

Blended cements S1, S2 and S3 bearing $10 \mathrm{wt} \%$ and $20 \mathrm{wt} \%$ BBA were tested for compressive and flexural strength as per EN 196-1 [39]. Prismatic $(4 \times 4 \times 16 \mathrm{~cm})$ mortar specimens were prepared with a sand/cement ratio of $3 / 1$ and a water/cement ratio of $1 / 2$, de-moulded after $24 \mathrm{~h}$ and cured at $20 \pm 1^{\circ} \mathrm{C}$ and $100 \%$ relative humidity until the test time $(2 \mathrm{~d}, 7 \mathrm{~d}, 28 \mathrm{~d}, 90 \mathrm{~d}, 180 \mathrm{~d}$ or $365 \mathrm{~d})$. Nine specimens per mix and age were tested for flexural strength and 18 for compressive strength.

\subsubsection{Strength activity index (SAI)}

The procedure followed was similar to the one proposed in EN 450-1 [42] for fly ash used as an admixture in concrete manufacture: a control mortar was prepared by mixing $1350 \mathrm{~g}$ of standard sand, $450 \mathrm{~g}$ of cement and $225 \mathrm{~mL}$ of distilled water in a planetary mixer for $5 \mathrm{~min}$. The $4 \times 4 \times 16 \mathrm{~cm}$ specimens prepared were de-moulded after $24 \mathrm{~h}$ and soaked in water at $20 \pm 1^{\circ} \mathrm{C}$ for $27 \mathrm{~d}$. In the eco-friendly cements $90 \mathrm{~g}(20 \%)$ of the cement was replaced with one of the three types of biomass studied (S1, S2 or S3). The resulting mortars had the same consistency as the reference, with a tolerance of $\pm 5 \mathrm{~mm}$.

The compressive strength findings shown are the mean of six measurements, represented as a percentage relative to the control mortar (SAI), as per Equation 1:

$S A I=($ oblended mortar $/$ бcontrol mortar $) \times 100$

where: $\sigma_{\text {blended mortar }}$ is the compressive strength of the additioned mortars and $\sigma_{\text {control mortar }}$ is the compressive strength of the reference mortar, both expressed in MPa.

\subsubsection{Eco-efficient material}

Inasmuch as a full life cycle analysis lies outside the aim of this study, the eco-efficiency of the new cements was found with a simplified calculation of the energy required relative to the energy required for OPC manufacture. 
The method, proposed by Hamidi et al [43], is based on the energy consumed in cement manufacture (heating raw materials, burning additions and clinkerisation) and grinding (clinker and BBA). The energy needed was consequently calculated as shown in Equation 2:

$E(k W \cdot h / t)=C \cdot\left(E_{\text {cement }}^{\text {process }}+E_{\text {cement }}^{\text {grinding }}\right)+B B A \cdot\left(E_{B B A}^{\text {process }}+E_{B B A}^{\text {grinding }}\right)$

where: $E$ is the energy consumed to produce $1 \mathrm{t}$ of binder; $C$ the proportion of cement $(1,0.90$ or $0.80)$; and $B B A$ the proportion of biomass bottom ash (0, 0.10 and 0.20$) ; E_{c e m e n t}^{\text {process }}$ and $E_{B B A}^{\text {process }}$ are the energy consumed $(\mathrm{kW} \cdot \mathrm{t} / \mathrm{h})$ in cement and BBA manufacture, respectively; and $E_{\text {cement }}^{\text {grinding }}$ and $E_{B B A}^{g r i n d i n g}$ the energy consumed $(\mathrm{kW} \cdot \mathrm{t} / \mathrm{h})$ in cement and BBA grinding, respectively.

The values obtained from Equation 2 were then used to calculate mortar energy performance with Equation 3:

$E_{\text {performance }}(k W \cdot h / t \cdot M P a)=\frac{E}{f_{c m}}$

where: $E$ is the energy consumed to produce $1 \mathrm{t}$ of binder and $f_{\mathrm{cm}}$ is the compressive strength of the mortars studied.

\subsection{Instrumental techniques}

The pore size distribution of the mortars was analysed with a Micromeritics Autopore IV 9500 mercury porosimeter operating at pressures of up to $33000 \mathrm{psi}(227.5 \mathrm{MPa})$ to measure pore diameters of $0.006 \mu \mathrm{m}$ to $175 \mu \mathrm{m}$. This trial was conducted to ASTM standard D 4404 [44].

The microstructure and morphology of the blended cements were analysed on a Hitachi S4800 (Tokyo, Japan) scattering electron microscope (SEM) coupled to a Bruker Nano XFlash 5030 silicon drift detector for energy-dispersive spectroscopic (EDX) determination of the chemical composition of the samples. The $\mathrm{C} / \mathrm{S}$ ratio of the gels was based on at least 30 microanalyses per mix at $40000 \mathrm{x}$ on samples secured to a metallic holder with a two-sided graphic adhesive after carbon coating the surface to ensure conductivity and detection of all the signals sought.

\section{Results and discussion}

\subsection{Eco-friendly cement compliance with chemical and physical requirements}

Table 1 lists the chemical specifications laid down in EN 197-1 [4] for ordinary cements. The data show that binary cements $\mathrm{OPC}+20 \mathrm{~S} 1, \mathrm{OPC}+20 \mathrm{~S} 2$ and $\mathrm{OPC}+20 \mathrm{~S} 3$ met the requirements to be deemed either cements II/A additioned at $6 \mathrm{wt} \%$ to $20 \mathrm{wt} \%$ or cements IV/A with $11 \mathrm{wt} \%$ to $35 \mathrm{wt} \%$ additions.

Table 1. Compliance of eco-friendly cements with chemical specifications 
The physical properties of the new cements designed are listed in Table 2, together with European cement legislation specifications [4]. The initial and end setting times were longer than in OPC, irrespective of the percentage and type of waste, whilst the values for S1 and S2 were similar and for S3 slightly higher than both at all replacement ratios. The latter observation was attributed to the mineralogy of the three types of waste, for S3 is the least reactive given its higher crystallinity [36] and lower reactive silica content. That translated into a delay in initial and end setting times for the cements bearing $10 \%$ and especially $20 \%$ S3. Nonetheless, the new binders met the standard requirements for ordinary strength $42.5 \mathrm{MPa}$ cements.

Table 2. Cement compliance with physical requirements

The longer initial and end setting times observed in the binary cements relative to OPC were probably due to a number of factors. Replacing the cement with this waste lowered the $C_{3} A$ content, which plays an important role in the early hours of cement hydration [45]. The very small (specific surfaces of $3.25 \mathrm{~m}^{2} / \mathrm{g}$ in S1, $0.77 \mathrm{~m}^{2} / \mathrm{g}$ in S2 and $6.63 \mathrm{~m}^{2} / \mathrm{g}$ in S3 [36]) waste particles competed for water, minimising the proportion available for cement hydration and thus retarding initial setting. Lastly, setting could also have been retarded by the presence of a heavy metal (such as $\mathrm{Zn}$ or $\mathrm{Cu}$ ) [46]. Delayed setting times were also observed for other cements containing ash sourced from woody waste combustion [46], a steam power plant burning logging industry waste and a paper pulp co-generation plant burning eucalyptus bark [24].

Expansion was not induced by any of the eco-friendly cements, all of which met the EN 197-1 requirement (slump $\leq 10 \mathrm{~mm}$ ).

\subsection{Pozzolanicity test}

Further to the $8 \mathrm{~d}$ and $15 \mathrm{~d}$ Frattini test results for the new cements shown in Figure 2, after $8 \mathrm{~d}$ (Figure 2(a)) the additioned cements were positioned slightly above the $\mathrm{CaO}$ solubility curve and rightward of the OPC reference cement. The rightward shift was wider with rising replacement ratios, irrespective of the type of addition (S1, S2 or S3), and attendant upon a decline in the concentration of the $\mathrm{Ca}^{2+}$ released during cement hydration.

Figure 2. Frattini diagrams for determining pozzolanicity at: (a) 8 days; and (b) 15 days In the $15 \mathrm{~d}$ trial, the cements with a $10 \%$ addition were also positioned above the solubility curve, whilst the materials bearing $20 \%$ waste lay below it due to the pozzolanic reaction-mediated 
reduction of the $\mathrm{Ca}^{2+}$ released in hydration. Therefore, further to the provisions of EN 197-1, cements $\mathrm{OPC}+20 \mathrm{~S} 1, \mathrm{OPC}+20 \mathrm{~S} 2$ and $\mathrm{PC}+20 \mathrm{~S} 3$ would qualify as pozzolanic cements (IV/A).

The percentage reduction of the maximum [CaO] for the $8 d$ and $15 d$ mixes containing $20 \%$ additions given in Table 3 shows that the $8 \mathrm{~d}$ cements all had negative values, indicating a position above the solubility curve and therefore no pozzolanic activity. Duly normalised, those negative values denote $0 \% \mathrm{CaO}$ removal. The positive values for the additioned $15 \mathrm{~d}$ cements confirmed pozzolanic activity in this BBA. In descending order pozzolanicity was $\mathrm{S} 1>\mathrm{S} 2>\mathrm{S} 3$ and the pozzolanicity indices were, for S1 $25.6 \%$, for S2 $6.8 \%$ and for S3 $0.4 \%$.

Table 3. Frattini test results for cements containing 20\% BBA

The index for S1 was close to the laboratory value reported by Wang et al. [47] for switchgrass combustion ash ( $30 \%)$ and lower than found for silica fume ( $75 \%$ ) and the $68 \%$ to $83 \%$ found for corncob ash laboratory-combusted at $400^{\circ} \mathrm{C}, 500^{\circ} \mathrm{C}$ or $600^{\circ} \mathrm{C}$ [48]. The values for [CaO] reduction in S2 and S3 were comparable to the 3.3\% observed by Memon and Khan [48] for corncob ash burnt at $700^{\circ} \mathrm{C}$.

\subsection{Mechanical properties of eco-friendly cements}

\subsubsection{Compressive and flexural strength}

As Figure 3 shows, the compressive strength of the $2 \mathrm{~d}$ mortars designed was consistently higher than $10 \mathrm{MPa}(42.5 \mathrm{~N})$ or $20 \mathrm{MPa}(42.5 \mathrm{R})$ and greater than or equal to $42.5 \mathrm{MPa}(42.5 \mathrm{~N} / 42.5 \mathrm{R})$ in the $28 \mathrm{~d}$ materials, denoting compliance with the mechanical specifications set out in EN 197-1 [4] for 42.5 MPa strength class cements.

Figure 3. Mortar compressive strength versus time

At early ages $(\leq 28 \mathrm{~d}$ ) compressive strength was lower in all the new cements than in the reference because the effect of clinker dilution prevailed over the pozzolanicity of the new additions; the gap widened with rising replacement ratios. At $\geq 90 \mathrm{~d}$, particularly after $180 \mathrm{~d}$, the new cements performed similarly to or better than the control cement. That finding was directly related to the changes induced by these additions in mortar microstructure, specifically pore structure refinement as discussed later in section 3.4.

Relative compressive strength is plotted versus time in Figure 4. The lesser strength loss in the $2 \mathrm{~d}$ and $7 \mathrm{~d} 10 \% \mathrm{~S} 3$ than in S1 or S2 cements was determined by its higher specific surface, the physical property predominating in SCMs lacking significant pozzolanicity at early ages. At later ages $(28 \mathrm{~d}$ 
to $180 \mathrm{~d}$ ) all the cements with $10 \%$ addition exhibited relative strength of $>1$, whereas the cements with $20 \%$ addition had relative strengths of $\sim 1$. All the $365 d$ cements, irrespective of type and percentage of waste, had relative strengths of over 1 . The failure of the cements with $20 \%$ addition to exhibit relative strength greater than 1 until $365 d$ attests to the long life of the pozzolanic reaction that offsets the strength loss induced by clinker replacement.

Figure 4. Relative compressive strength vs time

The relative strength findings were consistent with results for $5 \%$ and 10\% BBA from woody plant and forest waste combustion ash: García and Sousa-Coutinho [34] found relative strength in those $90 \mathrm{~d}$ mortars with those additions to be $>1$. Other authors, however [33, 35, 49], using $10 \%$ to $40 \%$ BBA from olive tree and other plant material combustion ash observed declines in strength relative to the reference of up to $30 \%$ and $45 \%$ for $20 \%$ and $40 \%$ replacement due to the effect of theses ashes on the pore structure of the new mortars.

A similar pattern was observed for flexural strength (Figure 5): after $365 d$ the new mortars exhibited flexural strength from $0.5 \%$ to $3 \%$ greater than in OPC, depending on the percentage and type of addition. The highest rise was recorded for S1, followed by S2 and S3 in that order, in keeping with their relative pozzolanicities.

Figure 5. Mortar flexural strength versus time

The data in Table 4 show that the inclusion of biomass waste as additions did not alter the llogarithmic regression between compressive or flexural strength curing age, with correlation coefficients $\left(R^{2}\right)$ consistently $>0.94$. A similar pattern was observed by Medina et al. [50] for ornamental granite industry sludge.

Table 4. Correlation between mechanical properties and curing age

\subsubsection{Significance of factors in mechanical strength}

The MANOVA results for the effect of the factors curing age ('age') and waste percentage ('PW') and type ('waste') and of their interactions on compressive and flexural strength are given in Table 5. Further to the data, all the factors except waste (values=S0 (without waste), S1, S2, S3) and their interactions had a significant effect on compressive strength ( $p$-value $<0.05)$. The findings for flexural strength were similar, except that the interaction among all the factors (age ${ }^{*} \mathrm{~W}^{*}$ waste) had no significant effect on the dependent variable ( $p$-value> 0.05 ).

Table 5. MANOVA values for mechanical strength 
The statistical model explained $99 \%$ of the variation in compressive and $97 \%$ in flexural strength. Table 5 shows that the factors age and PW affected the two variables similarly, with the former contributing over $90 \%$, and the latter around $2 \%$, to both. The interaction of the factors age $\mathrm{PW}$ explained $1 \%$ of the variation in flexural strength, and age ${ }^{*}$ waste $2 \%$. The rest of the factors had only a marginal effect on either variable.

The statistical models by mortar family $(\mathrm{OPC}+\mathrm{XY}$, where $X$ is the replacement ratio and $Y$ the type of waste) also showed that curing time and replacement ratio and their interaction had a significant effect ( $p$-value $<0.05 \%$ ) on compressive and flexural strength. Those models explained $96 \%$ of the variation observed, with no differences (see Figure 6) in the contribution of the factors [age ( $>93 \%)$ $>$ PW $(>2.5 \%)>$ age $\left.{ }^{*} \mathrm{PW}(>2.4 \%)\right]$ to the performance of mortars with different types of waste (S1, S2, S3). Those findings further support the lack of significance of the type of waste.

Figure 6. Participation of factors in the compressive and flexural strength of mortars bearing different types of waste: (a) curing age; (b) percentage of waste; (c) interaction age* percentage of waste

The groups resulting from Tukey's HSD multiple range tests for compressive and flexural strength in the mortar families (OPC+X and OPC+Y, where $X$ is $10 \%$ or $20 \%$ and $Y$ is S0 (no waste), S1, S2 or S3) are listed in Tables 6 and 7, by order of the highest mean value for the factor studied. Several inferences can be drawn from this table. Three groups were defined for early age $(\leq 28 \mathrm{~d})$ compressive and flexural strength, whereas for later ages one group was defined for flexural and two for compressive strength. In the $365 \mathrm{~d}$ mortars, the mean compressive strength was greater in the $10 \%$ additioned materials than in the $20 \%$ materials, and the latter value greater than in the unadditioned mortars $(10 \%>20 \%>0 \%)$. The former two were positioned in group 1 and the OPC in group 2. Likewise in the $365 \mathrm{~d}$ mortars, the type of waste (S0, S1, S2, S3) had no significant effect on mean mechanical performance. The mean compressive strength values for mortars with biomass waste differed significantly from the mean for the mortars with no waste (S0), with a $p$-value $<0.05$. Those findings were consistent with the pozzolanicity exhibited by the waste.

Table 6. HSD multiple range groups by age, and percentage and type of waste: compressive strength

Table 7. HSD multiple range groups by age, and percentage and type of waste: flexural strength

\subsubsection{Strength activity index}


The 28 d strength activity indices for the cements containing a 20\% addition, found with Equation 1, are shown in Figure 7(a). Although replacing cement with the three types of biomass waste induced a decline in strength relative to the reference, all the cements studied had SAI values of over the $75 \%$ required by ASTM C618 [51] for $28 \mathrm{~d}$ cements bearing $20 \%$ fly ash or natural pozzolans.

Figure 7. (a) Strength activity index for new $28 \mathrm{~d}$ cements; (b) correlation between $28 \mathrm{~d}$ strength activity index and $\mathrm{CaO}$ removed after $15 \mathrm{~d}$

Those findings were consistent with the results reported by Sarabér [52] and Jidrada [26], who observed $28 \mathrm{~d}$ strength activity indices greater than or equal to $77 \%$ for cements containing agricultural biomass, meat and bone meal and combined coal and biomass combustion ash.

Figure $7(b)$ attests to the good linear correlation $\left(R^{2}=0.96\right)$ between the $15 d$ Frattini test results and the $28 \mathrm{~d}$ strength activity index, in keeping with earlier observations by Mohammed et al. [53]. That correlation is attributable primarily to the higher strength (SAl) associated with the formation of additional C-S-H gels induced by intense portlandite reduction (Frattini test).

\subsection{Total porosity and pore diameter distribution in cements}

The total porosity and mean pore diameter $(4 \mathrm{~V} / \mathrm{A})$ values for the $7 \mathrm{~d}, 90 \mathrm{~d}$ and $365 \mathrm{~d}$ mortars given in Table 8 show that both declined over time, irrespective of the mortar. The mortars containing $10 \%$ waste had total porosity similar to that of the control, whereas the materials with $20 \%$ exhibited slightly greater porosity than the reference, although at $<13 \%$ the rise was smaller than the replacement ratio.

Table 8. Total porosity and mean pore diameter in $7 \mathrm{~d}, 90 \mathrm{~d}$ and $365 \mathrm{~d}$ mortars

The mean pore diameter values clearly attested to pore system refinement with rising age and replacement ratio, with a decline relative to OPC in $365 \mathrm{~d}$ mean pore size of $9 \%$ to $32 \%$ in mortars with $10 \%$ waste and $22 \%$ to $44 \%$ in the materials with $20 \%$ addition. Those values were greater than observed earlier by Moretti et al. [54], who recorded a $9 \%$ decline in cements containing $20 \%$ bagasse ash.

Further to the plots in Figures 8 and 9, both macropore volume and mean pore diameter were linearly correlated to compressive strength. The same pattern was observed for flexural strength.

Figure 8 shows that for a given mortar, as the macropore $(>0.05 \mu \mathrm{m})$ volume declined, compressive strength rose linearly $\left(R^{2} \geq 0.94\right)$, confirming this fraction's significant role in mechanical strength 
reported by other authors $[55,56]$. The graph further reveals that the mortars containing additions had a similar or smaller volume of macropores than conventional OPC.

Figure 8. Macropores volume vs compressive strength As may be deduced from Figure 9, pore system refinement translated into a linear rise $\left(R^{2} \geq 0.93\right)$ in compressive strength (see section 3.3), corroborating earlier findings reported by Neville [57], who contended that in cement-based materials pore diameter distribution must be analysed in addition to total porosity, for pore system refinement enhances mechanical performance (see Figures 3 and $5)$.

Figure 9. Mean pore diameter vs compressive strength Figure 10 plots the pore diameter distribution curves for $365 \mathrm{~d}$ mortars. The mortars containing $10 \%$ BBA had a 1.10 to 1.83 -fold (S2>S3>S1) greater volume of mesopores $(0.05 \mu \mathrm{m}<\Phi<0.007 \mu \mathrm{m})$ than the OPC mortar, and those with 20\% BBA, 1.55 to 1.93 -fold greater (S2>S3>S1). The figure also clearly shows that the inclusion of the additions induced a rise in the capillary pore $(0.01 \mu \mathrm{m}<\Phi<0.007 \mu \mathrm{m})$ fraction. Here also, the behaviour observed was intrinsically related to waste pozzolanicity and the formation of extra C-S-H gel that filled the pores at later ages [58].

Figure 10. Pore diameter distribution in $365 \mathrm{~d}$ mortar

\subsection{Microstructure}

Figure 11 depicts the microstructure of $2 \mathrm{~d}$ and $365 \mathrm{~d}$ OPC and OPC+20S2 mortars. Irrespective of age, the partial replacement of cement with waste had no adverse effect on matrix uniformity nor did it alter cement hydration products (C-S-H gel, portlandite plates and ettringite needles or rods) or the presence of sand. The traces of unreacted addition in the $2 \mathrm{~d}$ new mortars disappeared with hydration time due to SCM pozzolanicity. The reaction mechanism involved is known to consist in $\mathrm{OH}^{-}$ion-mediated breakage of $\mathrm{Si}-\mathrm{O}$ and $\mathrm{Al}-\mathrm{O}$ bonds and the reaction of silicon and aluminium anions with $\mathrm{Ca}^{2+}$ cations in the bottom ash, giving rise to $\mathrm{C}-\mathrm{S}-\mathrm{H}$ gels that form on the surface of the waste (SCM - see Figure 11) [58].

Figure 11. SEM micrographs of $2 d$ and $365 d$ mortars: (a) $2 d$ OPC (1000x); (b) $2 d$ OPC+20S2 (1000x); (c) 365 d OPC (4000x); and (d) 365 d OPC+20S2 (4000x) [Note: $\boldsymbol{C H}$, portlandite; $\boldsymbol{C}-\boldsymbol{S}-\boldsymbol{H}$ gel, calcium silicate hydrate gel; Ett, ettringite; SCMs, supplementary cementitious materials] The calcium silicate hydrate gels (C-S-H gels) in the $2 \mathrm{~d}$ and $365 \mathrm{~d}$ mortars depicted in Figure 12 densified the matrix, which at the later age was compact, continuous and strong. These C-S-H 
materials would be type I gels on the Diamond [59] scale, given their common fibrous structure. The same morphology was reported by Zhang et al. [60], who noted that this typology was typical of cement paste or $\mathrm{C}_{3} \mathrm{~S}$ hydration, particularly when the materials are cured at high humidity.

Figure 12. SEM micrographs of C-S-H gel in: a) 2 d OPC; b) 2 d OPC+20S2; c) 365 d OPC; and d) 365 d OPC+20S2

The calcium-silicon (C/S) ratio in the C-S-H gels in the reference OPC mortar was $2.04 \pm 0.10$ and $1.61 \pm 0.10$ in $\mathrm{S} 1, \mathrm{~S} 2$ and $\mathrm{S} 3$. The $\mathrm{C} / \mathrm{S}$ ratios in the new BBA mortars lay within the usual range $(1.2$ to 2.3) for $\mathrm{C}-\mathrm{S}-\mathrm{H}$ gels in commercial cements $[58,61]$. The lower $\mathrm{C} / \mathrm{S}$ ratios in the BBA than in the OPC mortars were consistent with the range of values $(\mathrm{C} / \mathrm{S}=0.98$ to 1.88$)$ observed by Wang et al. [62] for pastes containing fly ash.

The C-S-H gels in the new cements also took up potassium in their structure, presumably in the interlayer or on the gel surface to offset the negative charges [63]. The $\mathrm{K} / \mathrm{Ca}$ ratio found was 0.04 and the $\mathrm{K} / \mathrm{Si}$ ratio 0.03 , both of which were higher than the 0.01 [64] for unadditioned cements and near the value $(\mathrm{K} / \mathrm{Si} \approx 0.02)[65]$ observed for synthetic gels with a $\mathrm{C} / \mathrm{S}$ ratio of 1.6 in which the uptake of these alkalis was studied [66]. As observed in earlier research [58,65, 67], that uptake was favoured when the $\mathrm{C} / \mathrm{S}$ ratio declined and the $\mathrm{Ca}(\mathrm{OH})_{2}$ content was lower, both of which conditions are found in the presence of additions.

The portlandite store visible in Figure 13 consisted in elongated hexagonal crystals with well-defined edges resulting from the hydration of the calcium silicates alite and belite. The crystal size observed, under $10 \mu \mathrm{m}$ wide, concurred with findings reported by both Neville [57] and Metha and Monteiro [56].

Figure 13. Portlandite store: a) 365 d OPC (6000x); b) 365 d OPC+20S2 (5000x) The micrographs in Figure 14 show the ettringite (Et) deposits [68], with longer and thinner needlelike crystals in the mortars containing additions (Figure 13b)) than in the reference mortars (Figure 13a)), as Hewlett [58] observed for pozzolan-bearing cements.

Figure 14. Ettringite needles a) 365 d OPC (10 000x); b) 365 d OPC+20S2 (13 000x) This hydration product was found locally and in small quantities in all the mortars, primarily inside pores (where it normally forms, in addition to cracks), given the presence of the specific conditions required for its formation, including pressure and ionic species, particularly $\mathrm{Al}(\mathrm{OH})^{4-}[69]$.

\subsection{Eco-efficient material}


Table 9 lists the values used to estimate the energy consumed to manufacture one tonne of binder. The values attributable to cement manufacture are known $[43,70,71]$. No references are available for BBA, however, for which consumption was estimated from the energy required to grind other materials. Grinding the fired clay-based fraction of construction waste $(\mathrm{CW})$ consumes $36 \mathrm{~kW} \cdot \mathrm{h} / \mathrm{t}$ (Asensio, [72]), for instance, whilst Hamidi et al. [43] estimated the value for andesite to be $75 \mathrm{~kW} \cdot \mathrm{h} / \mathrm{t}$. Given that BBA is softer than those materials, consumption close to the $\mathrm{CW}$ value was taken to be the least favourable.

Table 9. Values used to calculate the energy consumed

The energy consumption per MPa of strength versus BBA content plot in Figure 15 shows that the BBA-bearing cements had higher energy performance than OPC, consuming less energy to manufacture a cement with the same mechanical strength. Consumption continued to decline with rising replacement ratio and curing age, with the $28 \mathrm{~d}$ materials consuming minimally $4 \%$ less and the $365 \mathrm{~d}$ mortars at least $15 \%$ less than OPC.

Figure 15. Energy performance in $28 \mathrm{~d}$ and $365 \mathrm{~d}$ mortars

The use of BBA as a supplementary cementitious material would also entail $\mathrm{CO}_{2}$ emissions abatement at rates near the replacement percentage, as observed by a number of authors for other SCMs: fly ash, $20 \%[73,74]$ ( $\Delta=-19.8 \% /-17.8 \% \mathrm{CO}_{2}$ emissions); blast furnace slag, 35\% [73] ( $\Delta=-$ 33.7\% $\mathrm{CO}_{2}$ emissions); coal spoils burnt at $600{ }^{\circ} \mathrm{C}, 20 \%[70]$ ( $\Delta=-12.0 \% \mathrm{CO}_{2}$ emissions); steel slag, $10 \%[75]\left(\Delta=-9.5 \% \mathrm{CO}_{2}\right.$ emissions $)$.

\section{Conclusions}

The following conclusions can be drawn from this study.

- New cements containing 10 wt $\%$ or 20 wt\% S1-, S2- or S3-type BBA are EN 197-1-compliant in terms of chloride and sulfate content.

- The pozzolanicity test findings show that the new cements with $20 \%$ BBA (irrespective of type) qualify as CEM IV/A (11\% to $35 \%$ ) pozzolanic cements.

- Adding $10 \%$ or $20 \%$ biomass waste (S1, S2, S3) to cement pastes retards initial setting times 1.5 to 1.9 -fold relative to OPC pastes. The new cements have no adverse effect on workability, meeting the EN-197-1 minimum initial setting time requirement ( $\geq 60 \mathrm{~min})$. These eco-efficient cements also comply with EN 197-1 soundness specifications. 
- BBA-bearing mortar mechanical strength declines as the replacement ratio rises, particularly at early ages, although the difference narrows with curing time due to the pozzolanic activity of the additions. After 365 d mortars S1, S2 and S3 exhibit higher mechanical performance than OPC mortar, with strength rising relative to OPC by $6.5 \%$ in $10 \%$ additions and $3.5 \%$ in mortars with $20 \%$ waste.

- Irrespective of the waste type and replacement ratio, the mortars designed are EN 197-1compliant for strength class $42.5 \mathrm{MPa}$.

- The type of waste (S1, S2, S3) has no statistically significant effect ( $p$-value>0.05) on long-term mechanical performance in the new cements. The variation observed in performance is explained primarily by curing time (>90\%) and to a lesser extent by the replacement ratio $(>2 \%)$ and the interaction between the two $(>2 \%)$.

- SCM pozzolanicity induces a slight rise in total porosity in the $365 \mathrm{~d}$ mortars, at a rate lower than the replacement ratio. The additions also refine the pore structure, with a macropore $(>0.05 \mu \mathrm{m})$ volume similar to that observed in OPC and a $5 \%$ increase in the mesopore $(0.05<\Phi<0.007 \mu \mathrm{m})$ fraction with $10 \%$ replacement and a $30 \%$ rise in the materials with $20 \%$ waste.

- S1, S2 and S3 induce no significant morphological change in the hydration products (C-S-H gel, portlandite and ettringite), although their inclusion lowers the $\mathrm{C} / \mathrm{S}$ ratio and favours $\mathrm{K}$ uptake in the $\mathrm{C}-\mathrm{S}-\mathrm{H}$ gels as well as the formation of longer ettringite needles.

- The new cements exhibit higher energy performance than OPC, requiring less energy to produce a cement with the same compressive strength.

The BBA generated in biomass-fuelled electric power plants could be used to manufacture ecoefficient, lower clinker content II/A and IV/A cements, with all the associated economic, social and environmental benefits ensuing.

\section{Acknowledgements}

This research was funded by the Spanish Ministry of Economy and Competitiveness (BIA201565558-C3-1-2-3R and BIA2016-76643-C3-1-R) (MINECO/FEDER), as well as by the Government of Extremadura and the European Regional Development Fund (ERDF) under grant GR 18122 awarded to the MATERIA research group.

\section{References}


[1] R.J. Flatt, N. Roussel, C.R. Cheeseman, Concrete: An eco material that needs to be improved, J. Am. Ceram. Soc. 32 (2012) 2787-2798.

[2] E. Gartner, H. Hirao, A review of alternative approaches to the reduction of $\mathrm{CO} 2$ emissions associated with the manufacture of the binder phase in concrete, Cem. Concr. Res. 78 (2015) 126142.

[3] G. Oss Hendrik, C. Padovani Amy, Cement Manufacture and the Environment Part II: Environmental Challenges and Opportunities, J. Ind. Ecol. 7 (2008) 93-126.

[4] European Committee for Standardization EN 197-1. Cement. Composition, specifications and conformity criteria for common cements.

[5] European Union, Directive 2009/28/EC of the European Parliament and of the Council of 23 April 2009 on the promotion of the use of energy from renewable sources and amending and subsequently repealing Directives 2001/77/EC and 2003/30/EC, in, Official Journal of the European Union, 2009.

[6] T.y.C. Ministerio de Industria, Plan de energías renovables PER 2011-2020 de España, in, Madrid (Spain), 2011.

[7] J. Cuenca, J. Rodríguez, M. Martín-Morales, Z. Sánchez-Roldán, M. Zamorano, Effects of olive residue biomass fly ash as filler in self-compacting concrete, Constr. Build. Mater. 40 (2013) $702-$ 709.

[8] G. Wang, L. Shen, C. Sheng, Characterization of Biomass Ashes from Power Plants Firing Agricultural Residues, Energy \& Fuels 26 (2012) 102-111.

[9] A. Magdziarz, A.K. Dalai, J.A. Koziński, Chemical composition, character and reactivity of renewable fuel ashes, Fuel 176 (2016) 135-145.

[10] L.J.R. Nunes, J.C.O. Matias, J.P.S. Catalão, Biomass combustion systems: A review on the physical and chemical properties of the ashes, Renew. Sust. Energ. Rev. 53 (2016) 235-242.

[11] D. Eliche-Quesada, M.A. Felipe-Sesé, A.J. Moreno-Molina, F. Franco, A. Infantes-Molina, Investigation of using bottom or fly pine-olive pruning ash to produce environmental friendly ceramic materials, Appl. Clay Sci. 135 (2017) 333-346.

[12] M. Frías, E. Villar, H. Savastano, Brazilian sugar cane bagasse ashes from the cogeneration industry as active pozzolans for cement manufacture, Cem. Concr. Compos. 33 (2011) 490-496. 
[13] G.C. Cordeiro, R.D. Toledo Filho, L.s.M. Tavares, E.d.M.R. Fairbairn, Ultrafine grinding of sugar cane bagasse ash for application as pozzolanic admixture in concrete, Cem. Concr. Res. 39 (2009) 110-115.

[14] M. Frías, H. Savastano, E. Villar, M.I. Sánchez de Rojas, S. Santos, Characterization and properties of blended cement matrices containing activated bamboo leaf wastes, Cem. Concr. Compos. 34 (2012) 1019-1023.

[15] L. Rodier, K. Bilba, C. Onésippe, M.A. Arsène, Study of pozzolanic activity of bamboo stem ashes for use as partial replacement of cement, Mater. Struct. 50 (2016) 87.

[16] E. Villar-Cociña, E.V. Morales, S.F. Santos, H. Savastano Jr, M. Frías, Pozzolanic behavior of bamboo leaf ash: Characterization and determination of the kinetic parameters, Cem. Concr. Compos. 33 (2011) 68-73.

[17] N.M. Khalil, E.M. Hassan, M.M.E. Shakdofa, M. Farahat, Beneficiation of the huge waste quantities of barley and rice husks as well as coal fly ashes as additives for Portland cement, J. Ind. Eng. Chem. 20 (2014) 2998-3008.

[18] R.N. Gonzalez-Kunz, P. Pineda, A. Bras, L. Morillas, SPlant biomass ashes in cement-based building materials. Feasibility as eco-efficient structural mortars and grouts, Sust. Cities Soc. 31 (2017) 151-172.

[19] E.Y. Nakanishi, M. Frías, S. Martínez-Ramírez, S.F. Santos, M.S. Rodrigues, O. Rodríguez, H. Savastano Jr, Characterization and properties of elephant grass ashes as supplementary cementing material in pozzolan/Ca(OH) $)_{2}$ pastes, Constr. Build. Mater. 73 (2014) 391-398.

[20] C. Fernández-Pereira, J.A. de la Casa, A. Gómez-Barea, F. Arroyo, C. Leiva, Y. Luna, Application of biomass gasification fly ash for brick manufacturing, Fuel 90 (2011) 220-232.

[21] S.V. Vassilev, D. Baxter, L.K. Andersen, C.G. Vassileva, An overview of the chemical composition of biomass, Fuel 89 (2010) 913-933.

[22] D. Nagrockienè, A. Daugèla, Investigation into the properties of concrete modified with biomass combustion fly ash, Constr. Build. Mater. 174 (2018) 369-375.

[23] R. Rajamma, R.J. Ball, L.s.A.C. Tarelho, G.C. Allen, J.o.A. Labrincha, V.M. Ferreira, Characterisation and use of biomass fly ash in cement-based materials, J. Hazard. Mater. 172 (2009) 1049-1060. 
[24] R. Rajamma, L. Senff, M.J. Ribeiro, J.A. Labrincha, R.J. Ball, G.C. Allen, V.M. Ferreira, Biomass fly ash effect on fresh and hardened state properties of cement based materials, Compos. Pt. BEng. 77 (2015) 1-9.

[25] V. Horsakulthai, S. Phiuvanna, W. Kaenbud, Investigation on the corrosion resistance of bagasse-rice husk-wood ash blended cement concrete by impressed voltage, Constr. Build. Mater. 25 (2011) 54-60.

[26] P. Jidrada, G. Sua-iam, B. Chatveera, N. Makul, Recycling of combined coal-biomass ash from electric power plant waste as a cementitious material: characteristics and improvement, J. Mater. Cycles Waste Manag. 18 (2016) 527-540.

[27] T. Ramos, A.M. Matos, J. Sousa-Coutinho, Mortar with wood waste ash: Mechanical strength carbonation resistance and ASR expansion, Constr. Build. Mater. 49 (2013) 343-351.

[28] C.B. Cheah, M. Ramli, The implementation of wood waste ash as a partial cement replacement material in the production of structural grade concrete and mortar: An overview, Resour. Conserv. Recycl. 55 (2011) 669-685.

[29] M. Wyrzykowski, S. Ghourchian, S. Sinthupinyo, N. Chitvoranund, T. Chintana, P. Lura, Internal curing of high performance mortars with bottom ash, Cem. Concr. Compos. 71 (2016) 1-9.

[30] M. Cabrera, F. Agrela, J. Ayuso, A.P. Galvin, J. Rosales, Feasible use of biomass bottom ash in the manufacture of cement treated recycled materials, Mater. Struct. 49 (2016) 3227-3238.

[31] M. Cabrera, J. Rosales, J. Ayuso, J. Estaire, F. Agrela, Feasibility of using olive biomass bottom ash in the sub-bases of roads and rural paths, Constr. Build. Mater. 181 (2018) 266-275.

[32] J.A. de la Casa, E. Castro, Recycling of washed olive pomace ash for fired clay brick manufacturing, Constr. Build. Mater. 61 (2014) 320-326.

[33] J. Rosales, M. Cabrera, M.G. Beltrán, M. López, F. Agrela, Effects of treatments on biomass bottom ash applied to the manufacture of cement mortars, J. Clean Prod.154 (2017) 424-435.

[34] M.d.L. Garcia, J. Sousa-Coutinho, Strength and durability of cement with forest waste bottom ash, Constr. Build. Mater. 41 (2013) 897-910.

[35] V. Sklivaniti, P.E. Tsakiridis, N.S. Katsiotis, D. Velissariou, N. Pistofidis, D. Papageorgiou, M. Beazi, Valorisation of woody biomass bottom ash in Portland cement: A characterization and hydration study, Journal of Environmental Chemical Engineering 5 (2017) 205-213. 
[36] J.M. Medina, I.F. Sáez del Bosque, M. Frías, M.I. Sánchez de Rojas, C. Medina, Characterisation and valorisation of biomass waste as a possible addition in eco-cement design, Mater. Struct. 50 (2017) 207.

[37] S.V. Vassilev, D. Baxter, L.K. Andersen, C.G. Vassileva, An overview of the composition and application of biomass ash. Part 1. Phase-mineral and chemical composition and classification, Fuel 105 (2013) 40-76.

[38] S.V. Vassilev, D. Baxter, L.K. Andersen, C.G. Vassileva, T.J. Morgan, An overview of the organic and inorganic phase composition of biomass, Fuel 94 (2012) 1-33.

[39] European Committee for Standardization, EN 196-1. Methods of testing cement - Part 1: Determination of strength.

[40] European Committee for Standardization, EN 196-5. Methods of testing cement - Part 5: Pozzolanicity test for pozzolanic cement.

[41] European Committee for Standardization, EN 196-3. Methods of testing cement - Part 3: Determination of setting times and soundness.

[42] European Committee for Standardization, EN 450-1. Fly ash for concrete. Part 1: Definition, specifications and conformity criteria.

[43] M. Hamidi, L. Kacimi, M. Cyr, P. Clastres, Evaluation and improvement of pozzolanic activity of andesite for its use in eco-efficient cement, Constr. Build. Mater. 47 (2013) 1268-1277.

[44] American Society for Testing and Materials, D 4404-84: Test method for determination of pore volume and pore volume distribution of soil and rock by mercury intrusion porosimetry.

[45] A. Akkarapongtrakul, P. Julphunthong, T. Nochaiya, Setting time and microstructure of Portland cement-bottom ash-sugarcane bagasse ash pastes, Monatshefte für Chemie - Chemical Monthly, 148 (2017) 1355-1362.

[46] M. Berra, T. Mangialardi, A.E. Paolini, Reuse of woody biomass fly ash in cement-based materials, Constr. Build. Mater. 76 (2015) 286-296.

[47] Y. Wang, Y. Shao, M.D. Matovic, J.K. Whalen, Recycling of switchgrass combustion ash in cement: Characteristics and pozzolanic activity with chemical accelerators, Constr. Build. Mater. 73 (2014) 472-478.

[48] S.A. Memon, M.K. Khan, Ash blended cement composites: Eco-friendly and sustainable option for utilization of corncob ash, J. Clean Prod. 175 (2018) 442-455. 
[49] M.G. Beltrán, A. Barbudo, F. Agrela, J.R. Jiménez, J. de Brito, Mechanical performance of bedding mortars made with olive biomass bottom ash, Constr. Build. Mater. 112 (2016) 699-707. [50] G. Medina, I.F. Sáez del Bosque, M. Frías, M.I. Sánchez de Rojas, C. Medina, Granite quarry waste as a future eco-efficient supplementary cementitious material (SCM): Scientific and technical considerations, J. Clean Prod. 148 (2017) 467-476.

[51] American Society for Testing and Materials, ASTM C618-15. Standard specification for coal fly ash and raw or calcined natrual pozzolan for use in concrete.

[52] A.J. Sarabèr, Co-combustion and its impact on fly ash quality; full-scale experiments, Fuel Process. Technol. 128 (2014) 68-82.

[53] S. Mohammed, Processing, effect and reactivity assessment of artificial pozzolans obtained from clays and clay wastes: A review, Constr. Build. Mater. 140 (2017) 10-19.

[54] J.P. Moretti, A. Sales, V.A. Quarcioni, D.C.B. Silva, M.C.B. Oliveira, N.S. Pinto, L.W.S.L. Ramos, Pore size distribution of mortars produced with agroindustrial waste, J. Clean Prod. 187 (2018) 473-484.

[55] K.K. Aligizaki, Pore structure of cement-based materials. Testing, interpretation and requirements, Frist Edition ed., Taylor \& Francis, New York, 2006.

[56] P. Kumar Metha, P.J.M. Monteiro, CONCRETE: Microstructure, Properties and Materials, Third Edition ed., McGraw-Hill, United States of America, 2006.

[57] A.M. Neville, Properties of concrete, 1st ed., Longman Scientific \& Technical John Wiley \& Sons, Harlow (New York), 2008.

[58] P.C. Hewlett, Lea's Chemistry of Cement and Concrete, Fourth Edition ed., London, 1998.

[59] S. Diamond, Cement paste microestructure: an overview at several levels, in: Sleffield (Ed.) $7^{\text {th }}$ Congr. Hydraulic Cement pastes: Their structure and properties, 1976, pp. 2-30.

[60] Z. Zhang, G.W. Scherer, A. Bauer, Morphology of cementitious material during early hydration, Cem. Concr. Res. 107 (2018) 85-100.

[61] I.G. Richardson, The nature of C-S-H in hardened cements, Cem. Concr. Res. 29 (1999) 11311147.

[62] Q. Wang, J. Feng, P. Yan, The microstructure of 4-year-old hardened cement-fly ash paste, Constr. Build. Mater. 29 (2012) 114-119. 
[63] T.T.H. Bach, E. Chabas, I. Pochard, C. Cau Dit Coumes, J. Haas, F. Frizon, A. Nonat, Retention of alkali ions by hydrated low-pH cements: Mechanism and $\mathrm{Na}+/ \mathrm{K}+$ selectivity, Cem. Concr. Res. $51(2013) 14-21$

[64] H.F.W. Taylor, Cement Chemistry, Second Edition ed., Thomas Telford Publishing, London, 1997.

[65] B. Lothenbach, A. Nonat, Calcium silicate hydrates: Solid and liquid phase composition, Cem. Concr. Res. 78 (2015) 57-70.

[66] E. L'Hôpital, B. Lothenbach, K. Scrivener, D.A. Kulik, Alkali uptake in calcium alumina silicate hydrate (C-A-S-H), Cem. Concr. Res. 85 (2016) 122-136.

[67] S.-Y. Hong, F.P. Glasser, Alkali sorption by C-S-H and C-A-S-H gels: Part II. Role of alumina, Cem. Concr. Res. 32 (2002) 1101-1111.

[68] C. Medina, M. Frías, M.I. Sánchez de Rojas, Microstructure and properties of recycled concretes using ceramic sanitary ware industry waste as coarse aggregate, Constr. Build. Mater. 21 (2012) $112-118$

[69] H.F.W. Taylor, C. Famy, K.L. Scrivener, Delayed ettringite formation, Cem. Concr. Res. 31 (2001) 683-693.

[70] I. Arribas, I. Vegas, V. García, R. Vigil de la Villa, S. Martínez-Ramírez, M. Frías, The deterioration and environmental impact of binary cements containing thermally activated coal mining waste due to calcium leaching, J. Clean Prod. 183 (2018) 887-897.

[71] I.F. Sáez del Bosque, M. Frías, M.I. Sánchez de Rojas, C. Medina, Activation temperaturemediated mineralogical transformations in slate quarry sludge: Pozzolanic properties, Constr. Build. Mater. 187 (2018) 819-829.

[72] E. Asensio, Valorización de residuos de construcción y demolición como puzolanas alternativas para cementos eco-eficientes, Departamento: Química Inorgánica I, Universidad Complutense de Madrid, 2015.

[73] T. García-Segura, V. Yepes, J. Alcalá, Life cycle greenhouse gas emissions of blended cement concrete including carbonation and durability, The International Journal of Life Cycle Assessment 19 (2014) 3-12.

[74] M.U. Hossain, C.S. Poon, I.M.C. Lo, J.C.P. Cheng, Comparative LCA on using waste materials in the cement industry: A Hong Kong case study, Resour. Conserv. Recycl. 120 (2017) 199-208. 
[75] S.Z. Carvalho, F. Vernilli, B. Almeida, M.D. Oliveira, S.N. Silva, Reducing environmental impacts: The use of basic oxygen furnace slag in portland cement, J. Clean Prod. 172 (2018) 385390. 


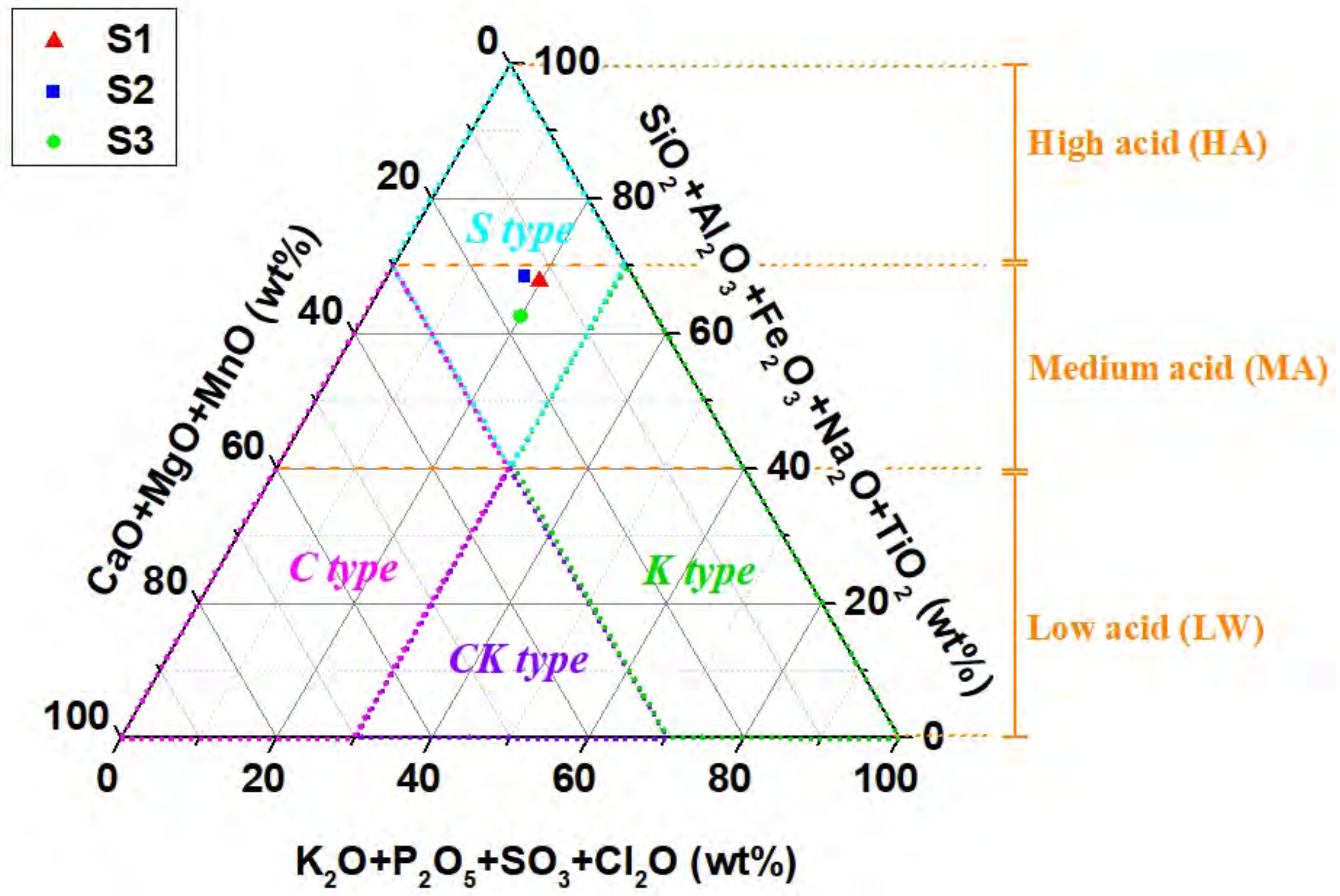



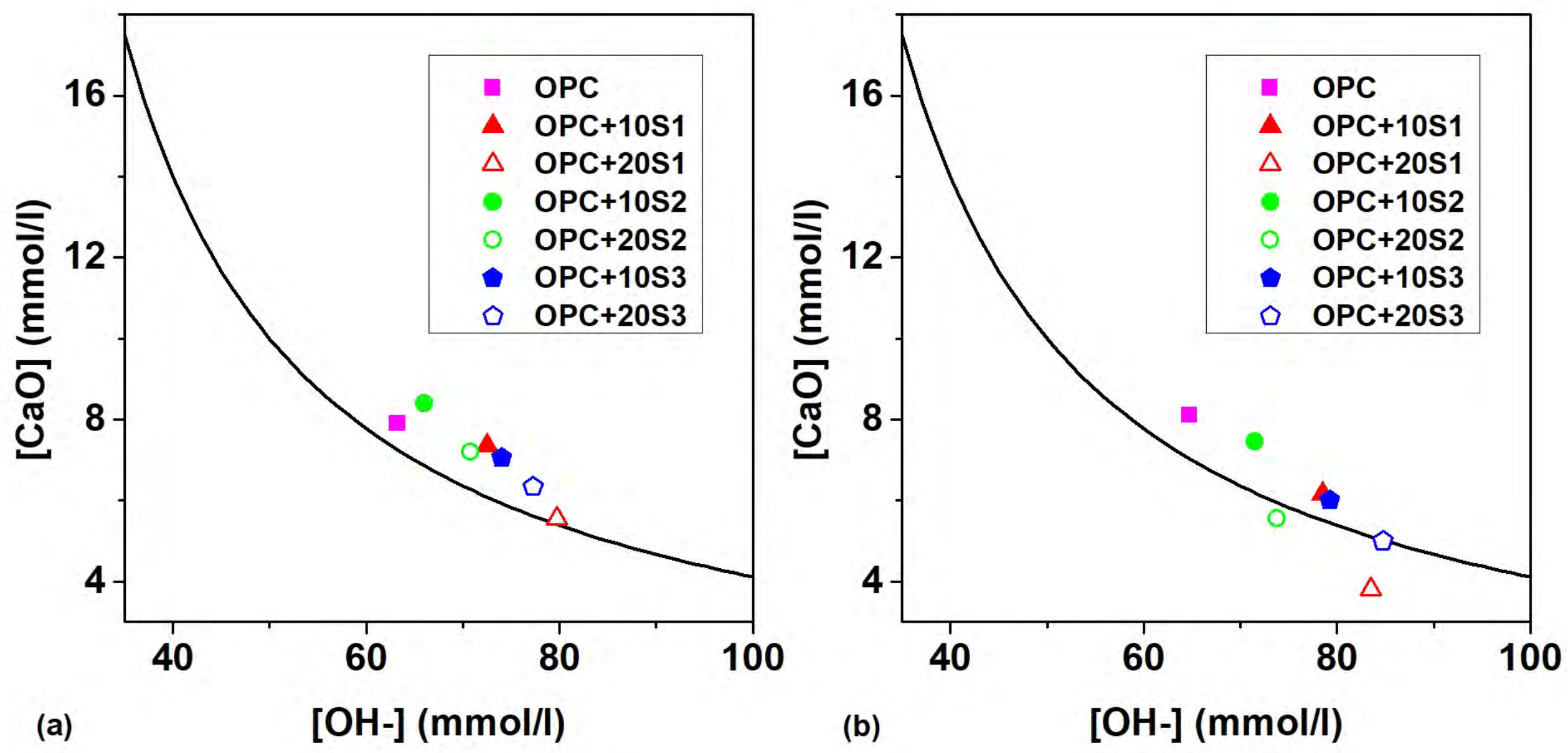
$\square \mathrm{OPC} \square \mathrm{OPC}+10 \mathrm{~S} 1 \square \mathrm{OPC}+20 \mathrm{~S} 1 \square \mathrm{OPC}+10 \mathrm{~S} 2 \square \mathrm{OPC}+20 \mathrm{~S} 2 \square \mathrm{OPC}+10 \mathrm{~S} 3 \square \mathrm{OPC}+20 \mathrm{S3}$

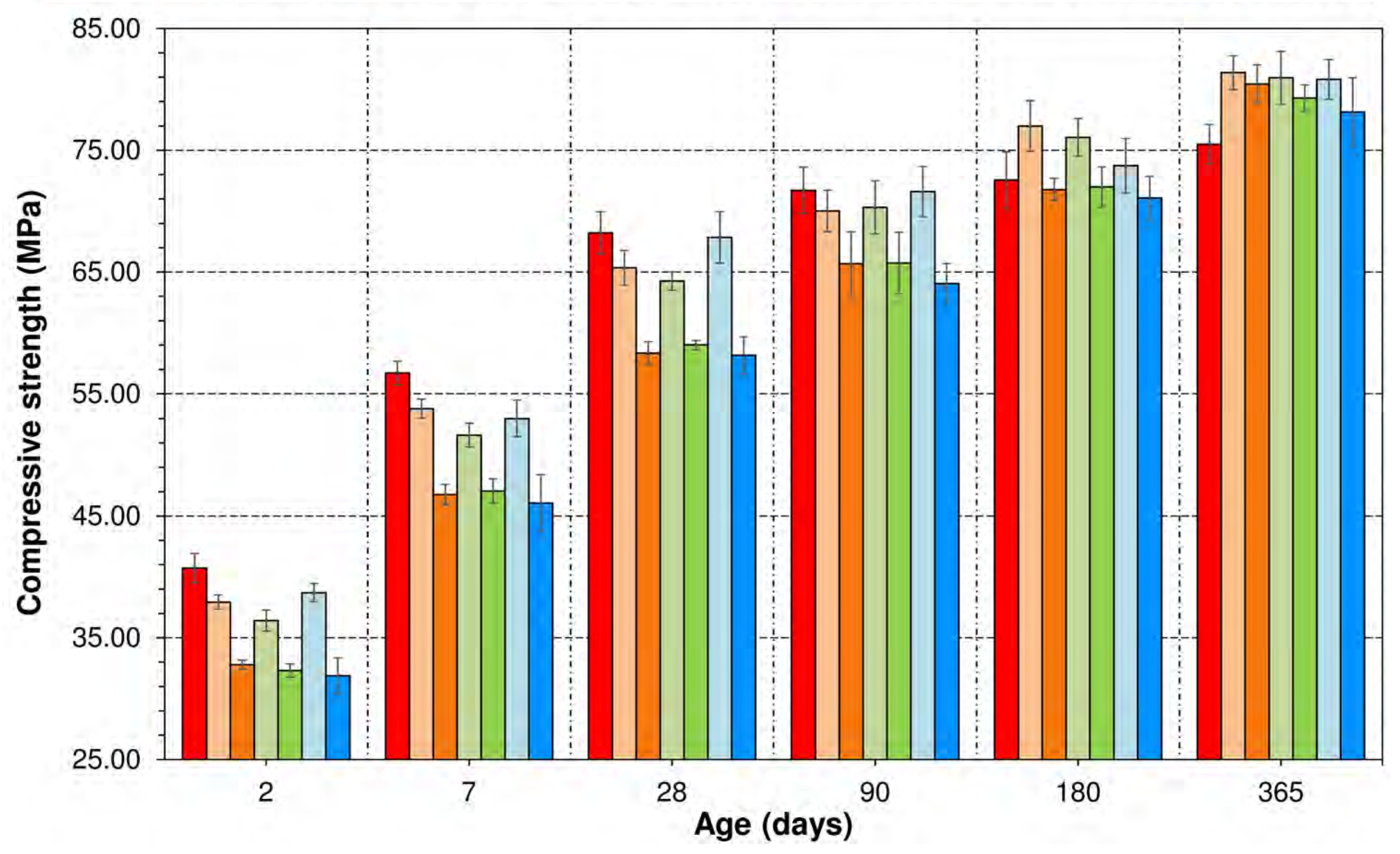




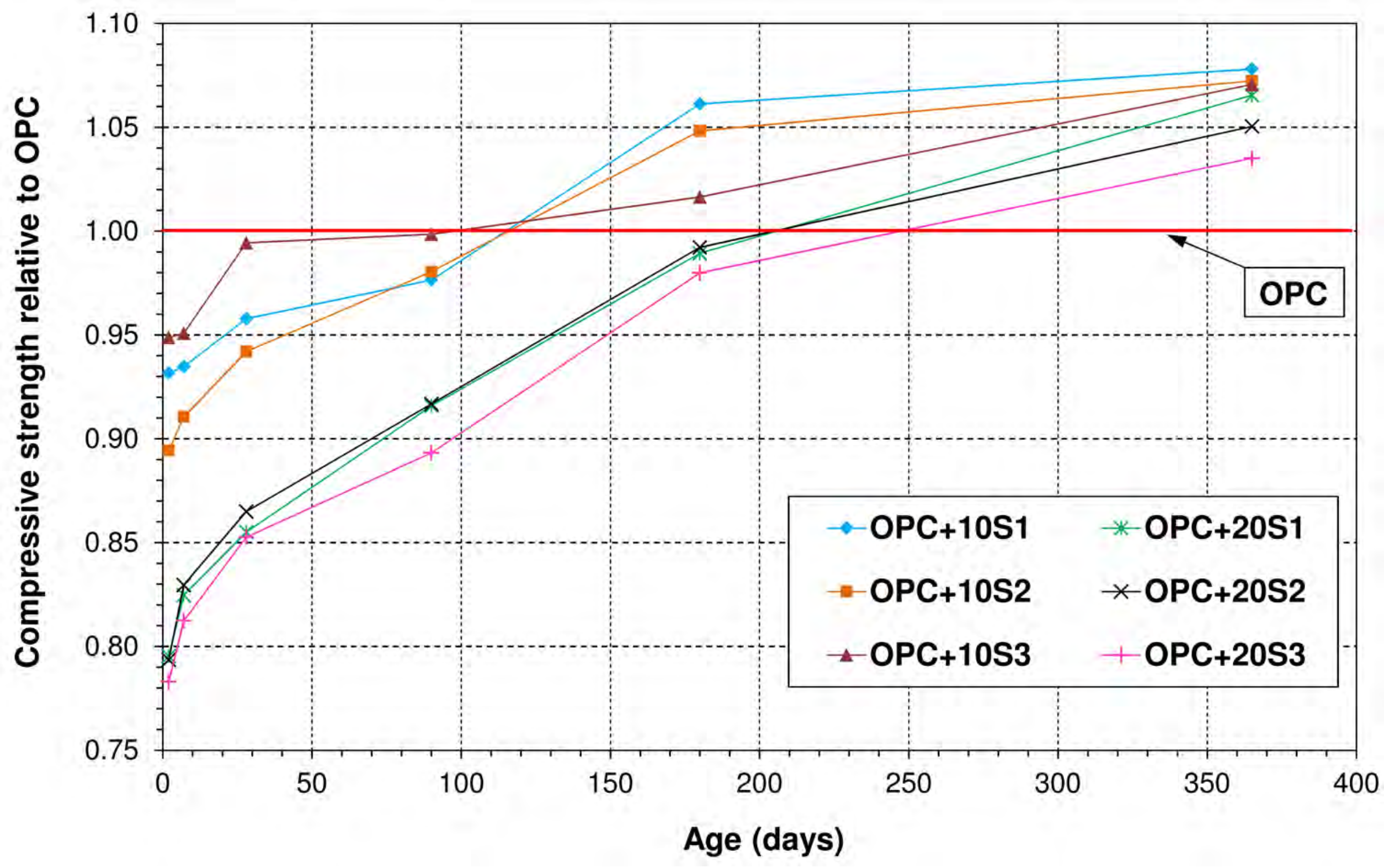




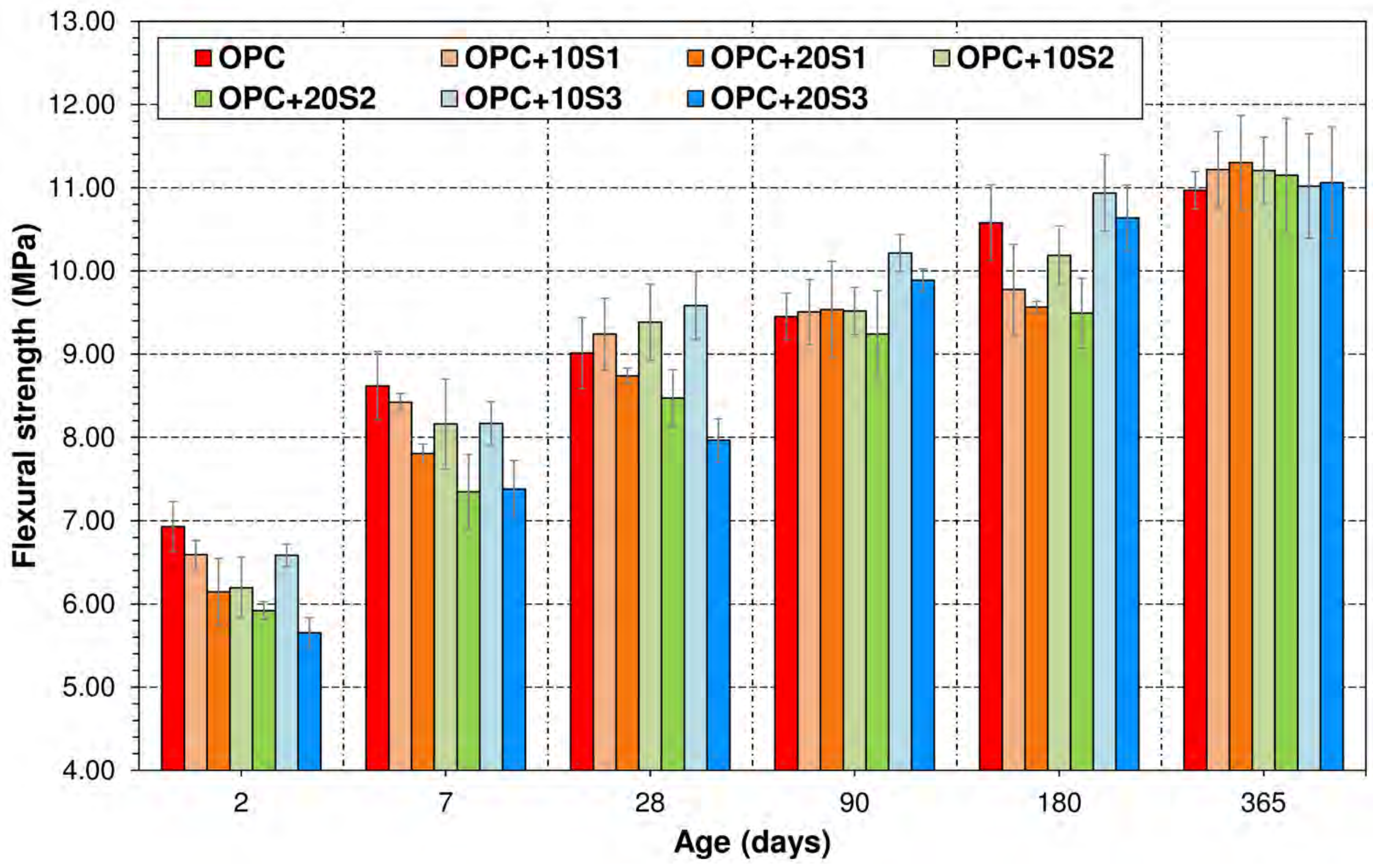


(a)

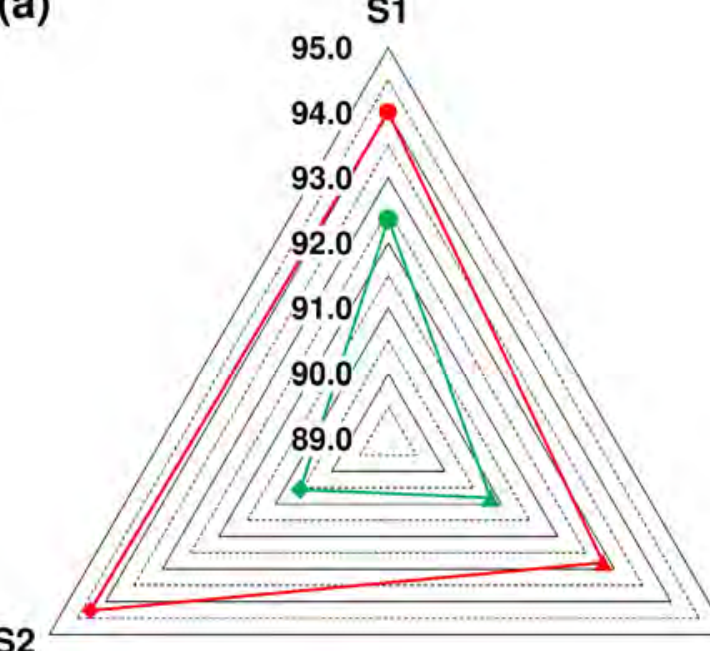

(b)

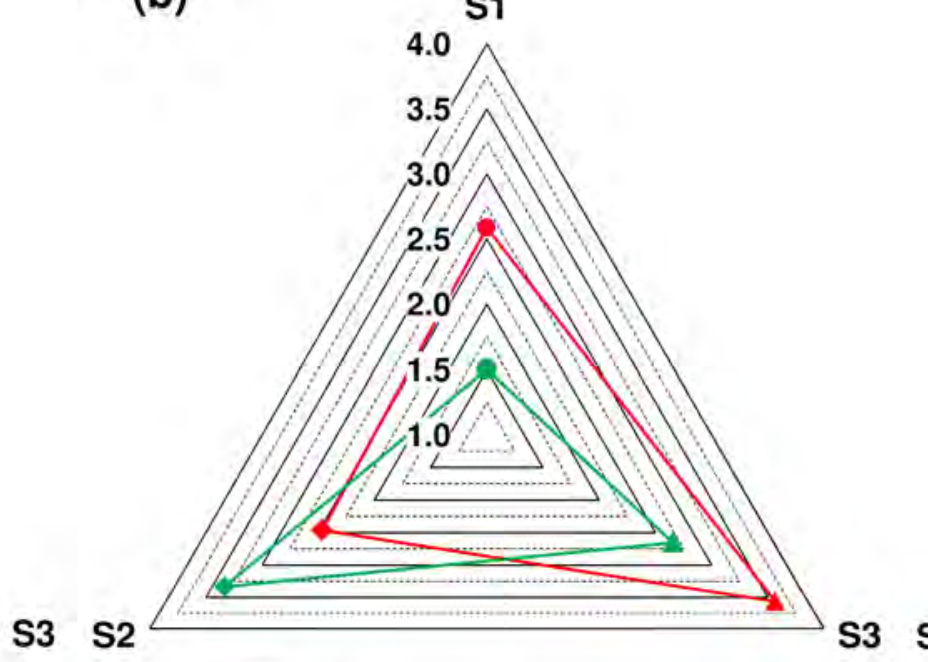

(c)

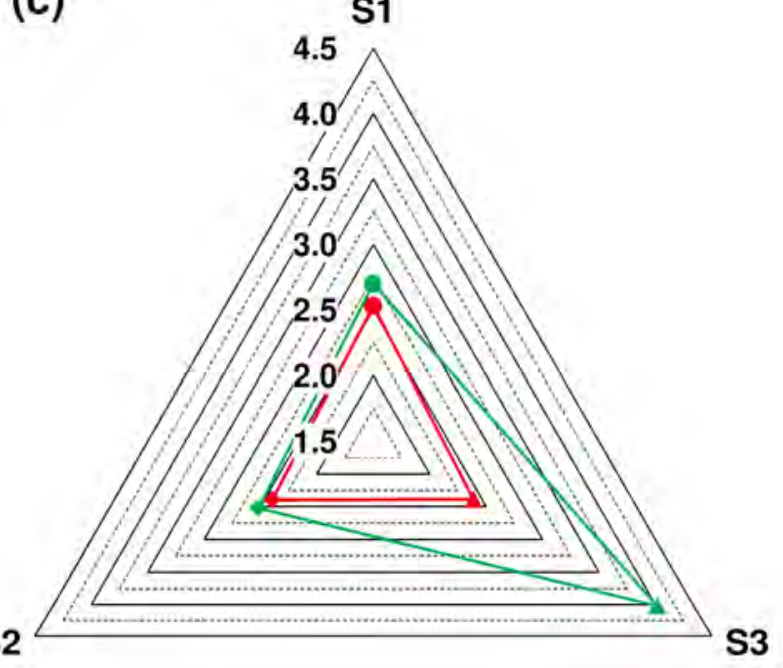

- Compressive strength - Flexural strength 


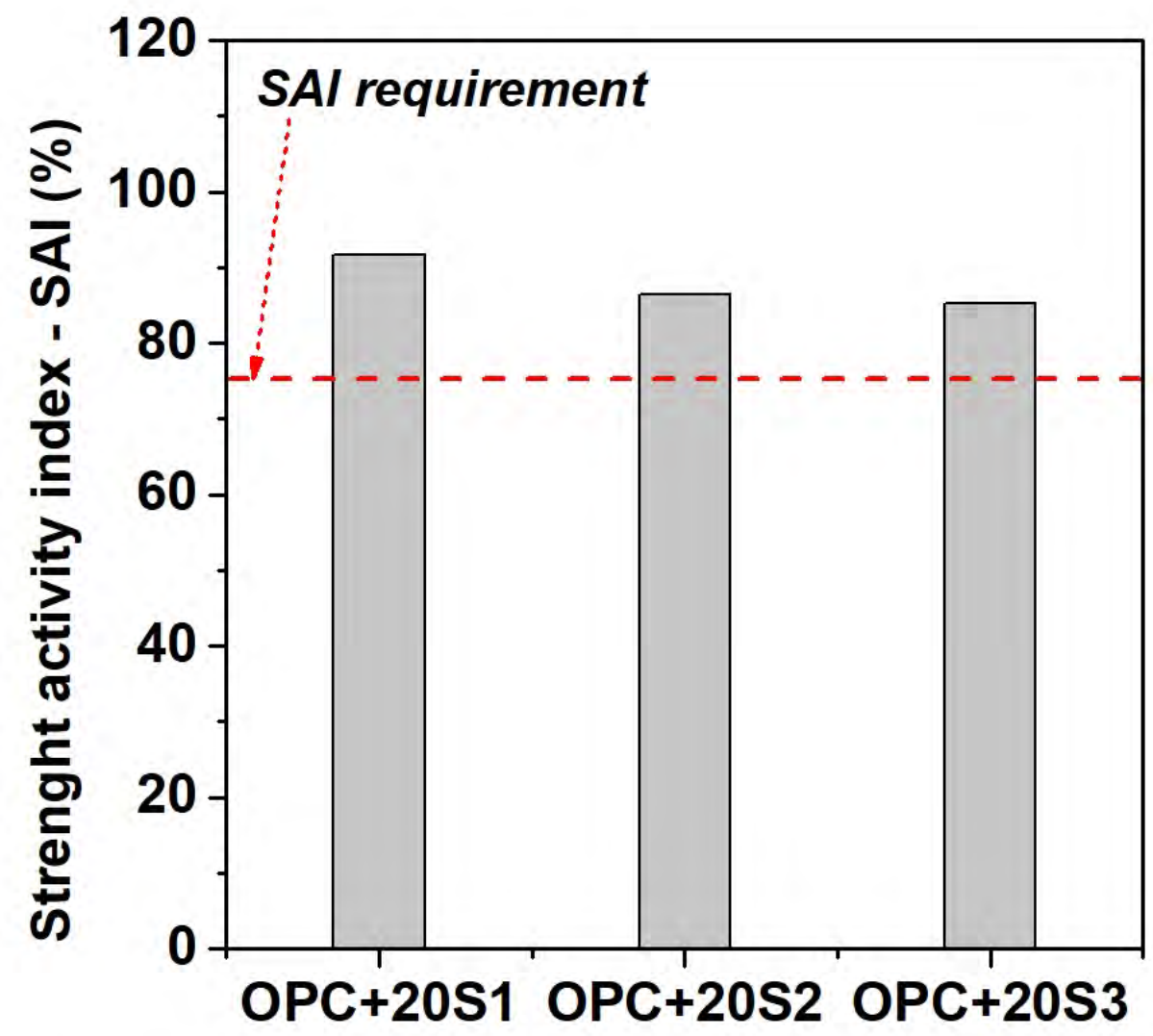

(a)

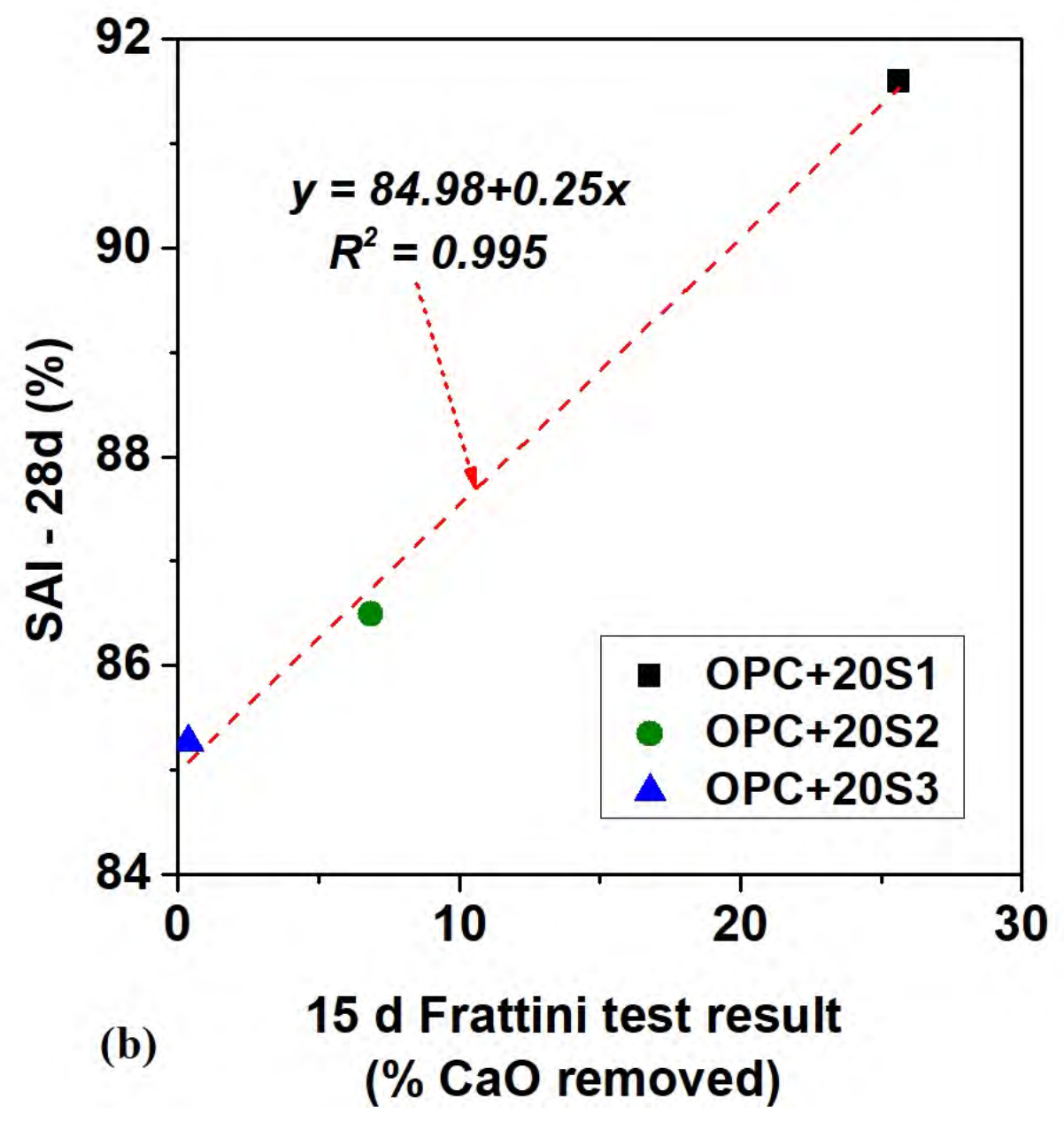




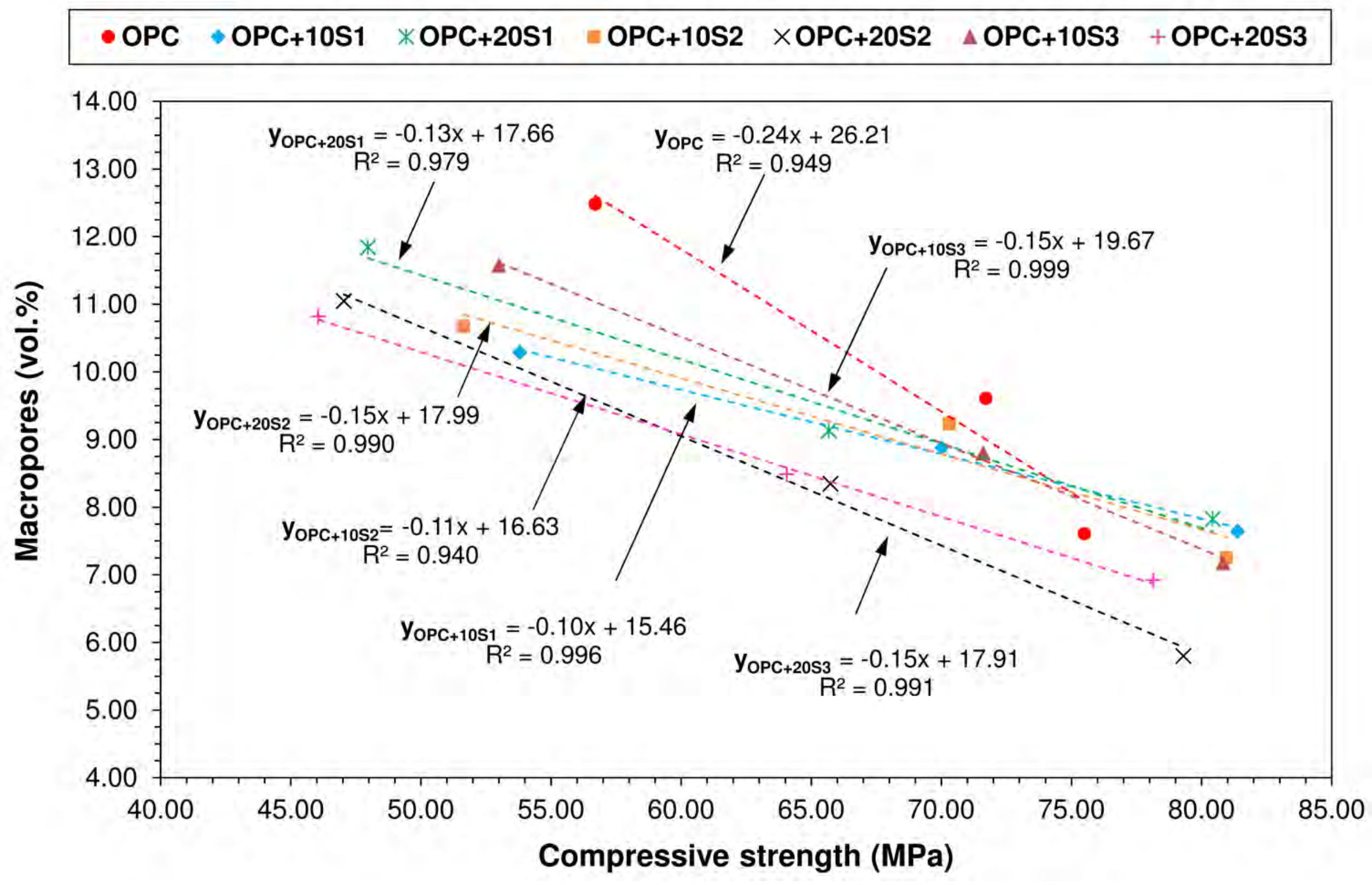


$\bullet$ OPC $\bullet$ OPC+10S1 $*$ OPC+20S1 OPC+10S2 $\times$ OPC+20S2 $\triangle \mathrm{OPC}+10 S 3+\mathrm{OPC}+20 \mathrm{~S} 3$

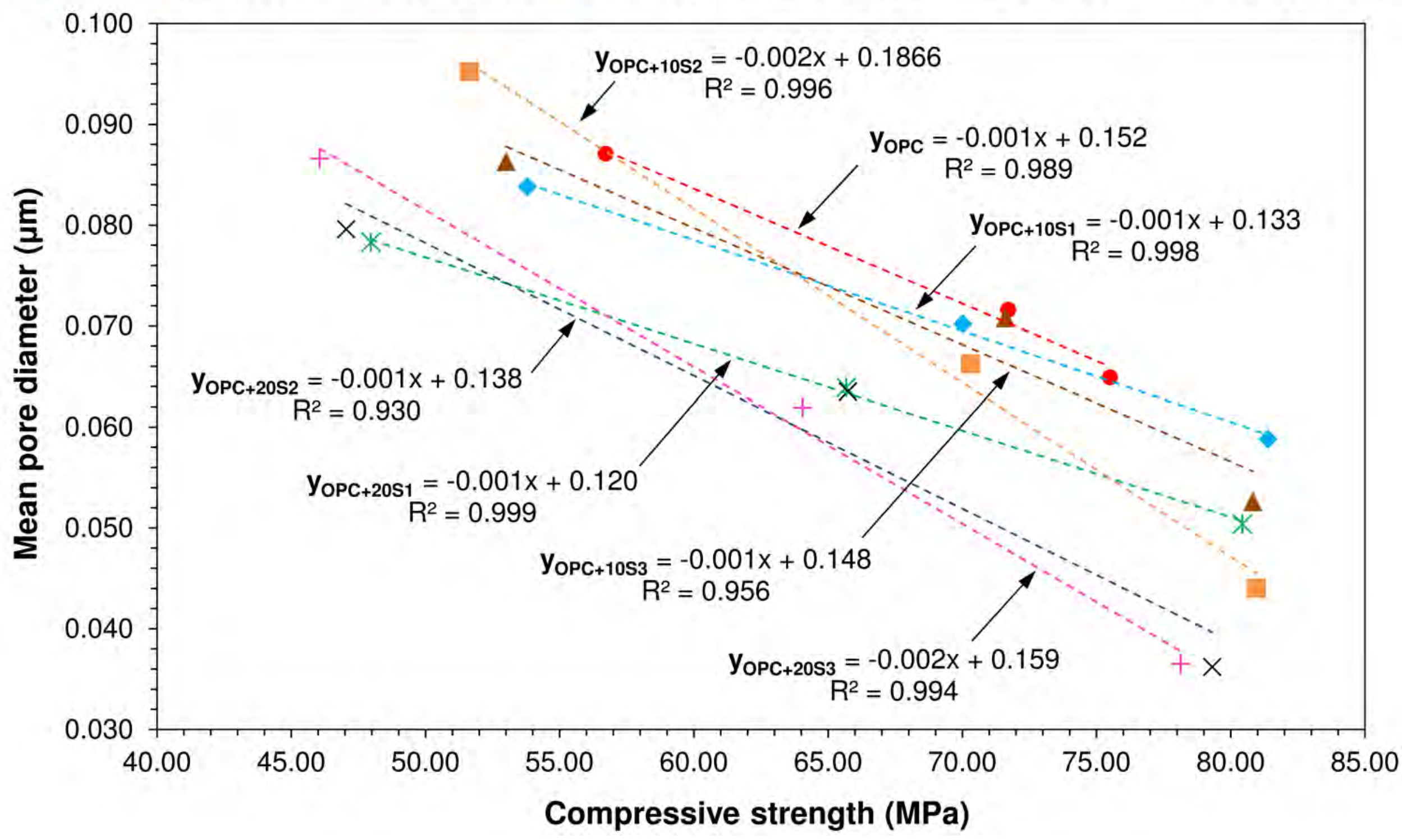




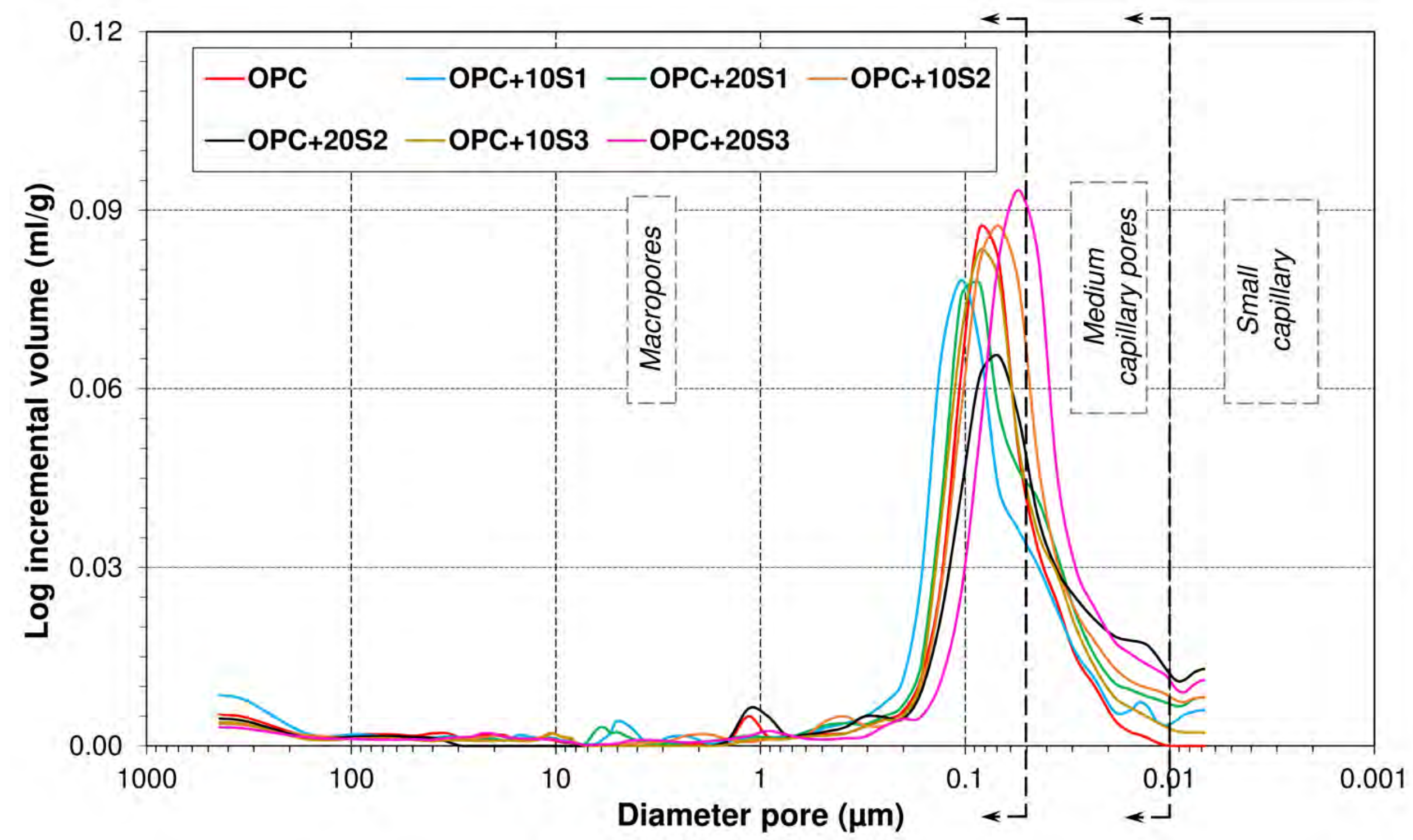



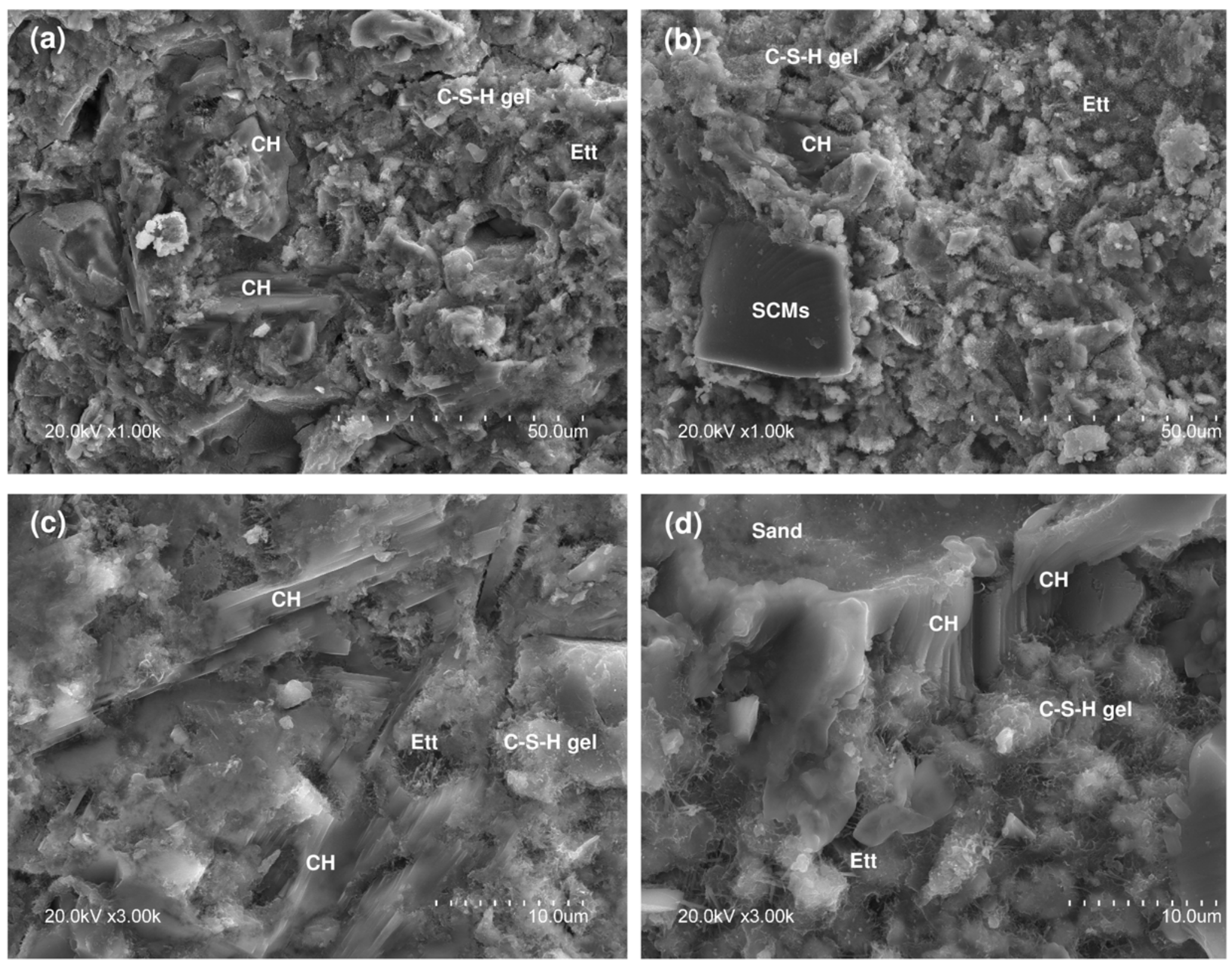

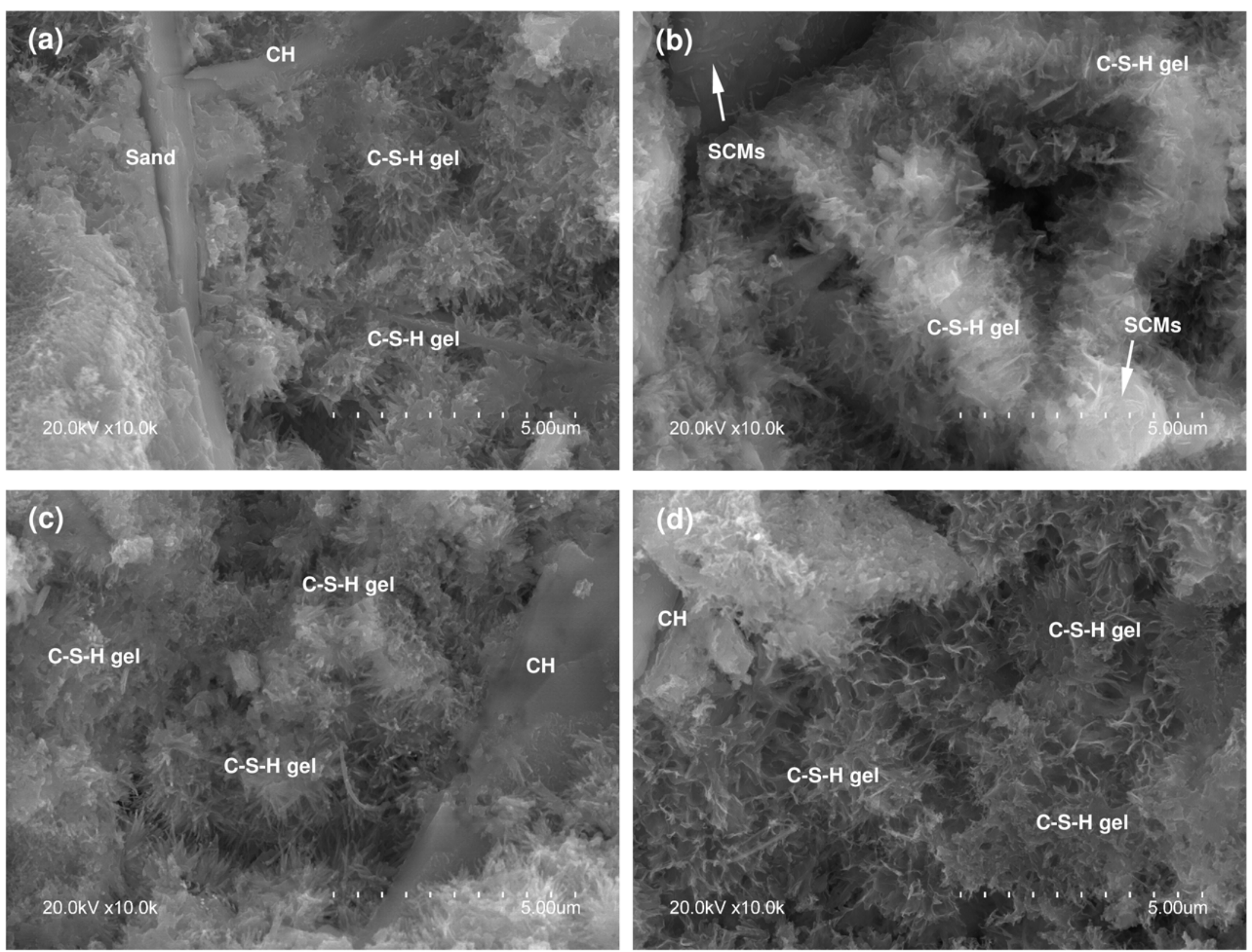


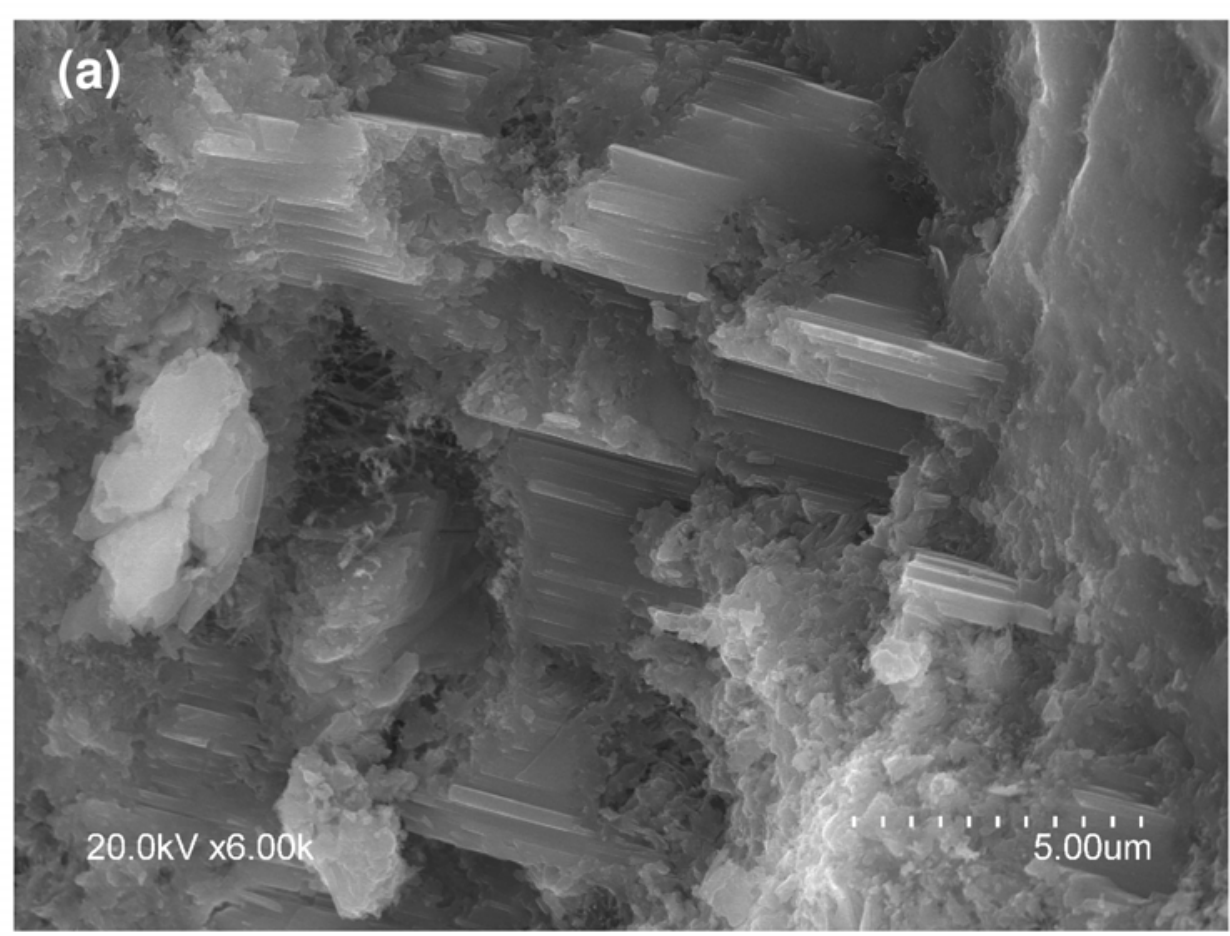

(b) 


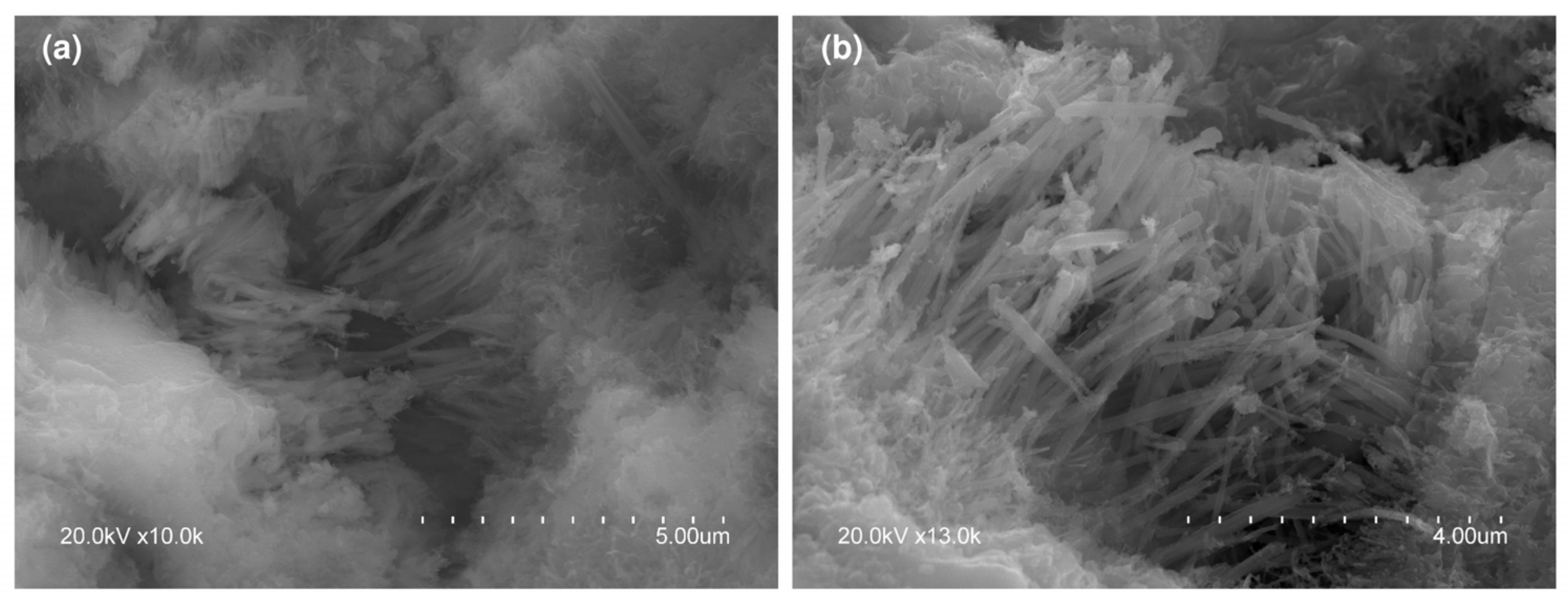




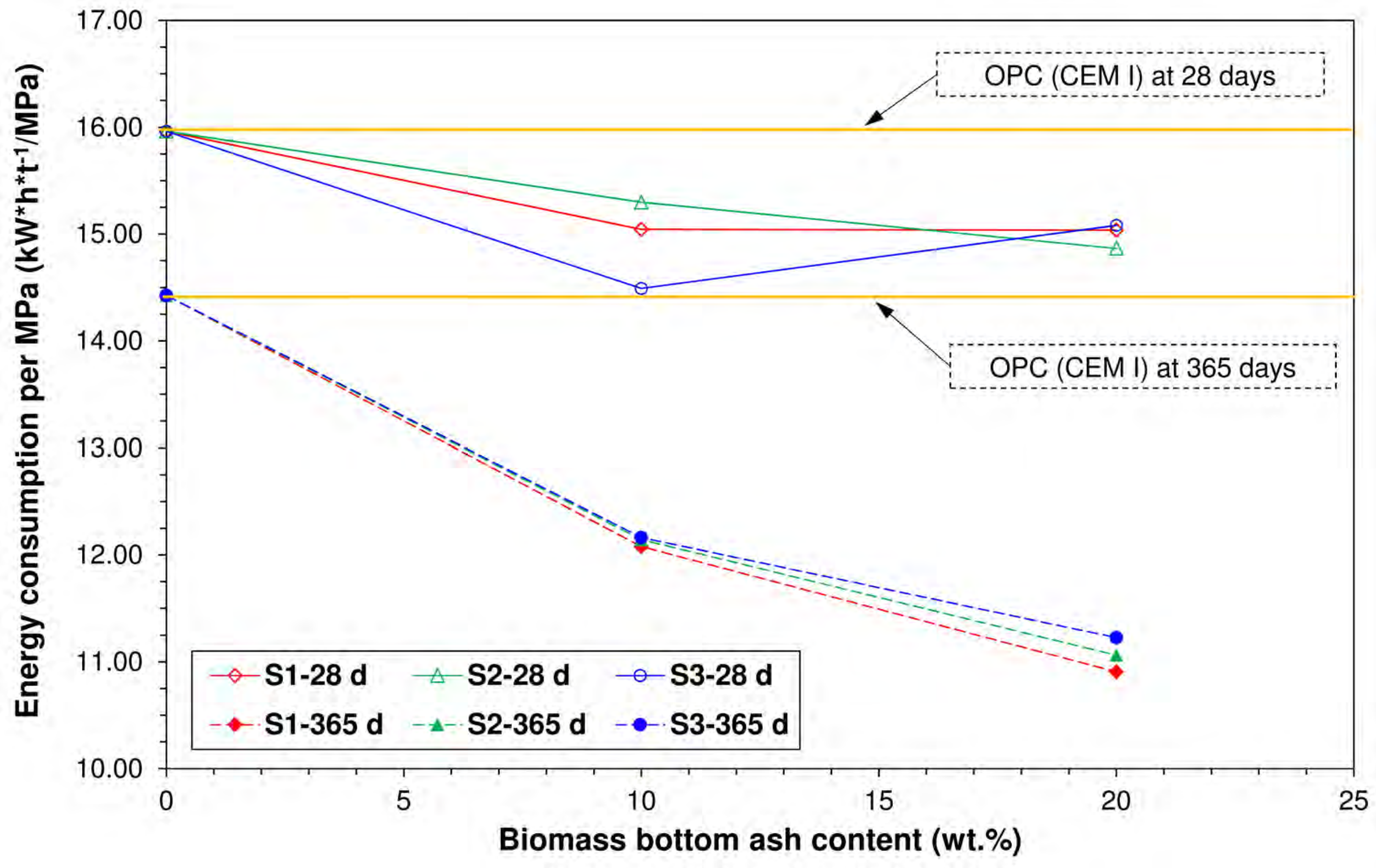


Table 1. Compliance of eco-friendly cements with chemical specifications

\begin{tabular}{|l|c|c|c|c|c|}
\hline \multirow{2}{*}{$\begin{array}{c}\text { Blended } \\
\text { cement }\end{array}$} & \multicolumn{2}{|c|}{$\begin{array}{c}\text { Chemical } \\
\text { constituent (wt\%) }\end{array}$} & \multirow{2}{*}{ Pozzolanicity } & \multicolumn{2}{|c|}{$\begin{array}{c}\text { Compliance with EN 197-1 [4] } \\
\text { requirements }\end{array}$} \\
\cline { 2 - 3 } & $\mathbf{S O}_{3}$ & $\mathbf{C l}$ & & CEM II/A $^{\mathbf{a}}$ & CEM IV/A $^{\mathbf{b}}$ \\
\hline OPC+10S1 & 3.04 & 0.003 & - & Yes & No \\
\hline OPC+10S2 & 3.03 & 0.006 & - & Yes & No \\
\hline OPC+10S3 & 3.06 & 0.020 & - & Yes & No \\
\hline OPC+20S1 & 2.77 & 0.006 & $\begin{array}{c}\text { Frattini } \\
\text { positive }\end{array}$ & Yes & Yes \\
\hline OPC+20S2 & 2.74 & 0.01 & $\begin{array}{c}\text { Frattini } \\
\text { positive }\end{array}$ & Yes & Yes \\
\hline OPC+20S3 & 2.80 & 0.04 & $\begin{array}{c}\text { Frattini } \\
\text { positive }\end{array}$ & Yes & Yes \\
\hline \multicolumn{7}{|c|}{ bSO $_{3} \leq 4.00 \% ; C l \leq 0.10 \%$ and Frattini positive } \\
\hline
\end{tabular}

Table 2. Cement compliance with physical requirements

\begin{tabular}{|c|c|c|c|}
\hline \multirow{3}{*}{ Cement } & \multicolumn{3}{|c|}{ Property } \\
\hline & \multicolumn{2}{|c|}{ Setting time $( \pm 10 \mathrm{~min})$} & \multirow{2}{*}{$\begin{array}{l}\text { Soundness } \\
(\mathrm{mm})\end{array}$} \\
\hline & Initial time & End time & \\
\hline OPC & 135.0 & 207.6 & 0 \\
\hline OPC+10S1 & 186.0 & 252.6 & 1 \\
\hline OPC+10S2 & 192.0 & 258.0 & 1 \\
\hline OPC+10S3 & 204.0 & 268.2 & 1 \\
\hline OPC+20S1 & 192.0 & 274.8 & 1 \\
\hline OPC+20S2 & 196.0 & 265.2 & 1 \\
\hline OPC+20S3 & 264.0 & 367.8 & 1 \\
\hline EN 197-1 [4] limit & $\geq 60$ & - & $\leq 10$ \\
\hline
\end{tabular}

Table 3. Frattini test results for cements containing $20 \%$ BBA

\begin{tabular}{|c|c|c|c|c|}
\hline \multirow{2}{*}{ Blended cement } & \multirow{2}{*}[\mathrm{OH}]{$(\mathrm{mmol} / \mathrm{l})$} & \multicolumn{2}{|c|}{$[\mathrm{CaO}](\mathrm{mmol} / \mathrm{l})$} & \multirow{2}{*}{$\begin{array}{c}{[\mathrm{CaO}]} \\
\text { reduction (\%) }\end{array}$} \\
\hline & & {$[\mathrm{CaO}]_{\text {test }}$} & $\operatorname{Max}[\mathrm{CaO}]$ & \\
\hline$O P C+20 S 1-8 d$ & 79.75 & 5.55 & 5.41 & -2.68 \\
\hline$O P C+20 S 1-15 d$ & 83.50 & 3.80 & 5.11 & 25.63 \\
\hline OPC+20S2-8d & 70.75 & 7.20 & 6.28 & -14.69 \\
\hline$O P C+20 S 2-15 d$ & 73.75 & 5.55 & 5.96 & 6.84 \\
\hline OPC+20S3-8d & 77.25 & 6.35 & 5.62 & -12.94 \\
\hline$O P C+20 S 3-15 d$ & 84.75 & 5.00 & 5.02 & 0.36 \\
\hline
\end{tabular}


Table 4. Correlation between mechanical properties and curing age

\begin{tabular}{|l|c|c|c|c|c|c|}
\hline \multirow{3}{*}{ Mortar } & \multicolumn{6}{|c|}{ Mechanical property } \\
\cline { 2 - 7 } & \multicolumn{3}{|c|}{ Compressive strength } & \multicolumn{3}{c|}{ Flexural strength } \\
\cline { 2 - 7 } & $\mathbf{A}$ & $\mathbf{B}$ & $\mathbf{R}^{\mathbf{2}}$ & $\mathbf{A}$ & $\mathbf{B}$ & $\mathbf{R}^{\mathbf{2}}$ \\
\hline $\mathrm{OPC}$ & 19.63 & 42.71 & 0.964 & 2.20 & 6.88 & 0.955 \\
\hline $\mathrm{OPC}+10 \mathrm{~S} 1$ & 24.23 & 37.68 & 0.997 & 2.26 & 6.65 & 0.944 \\
\hline $\mathrm{OPC}+20 \mathrm{~S} 1$ & 25.77 & 31.04 & 0.986 & 2.57 & 6.02 & 0.946 \\
\hline $\mathrm{OPC}+10 \mathrm{~S} 2$ & 25.01 & 35.82 & 0.997 & 2.63 & 6.24 & 0.974 \\
\hline $\mathrm{OPC}+20 \mathrm{~S} 2$ & 26.25 & 30.12 & 0.986 & 2.67 & 5.68 & 0.949 \\
\hline $\mathrm{OPC}+10 \mathrm{S3}$ & 23.58 & 38.60 & 0.981 & 2.55 & 6.59 & 0.982 \\
\hline $\mathrm{OPC}+20 \mathrm{S3}$ & 25.90 & 30.14 & 0.990 & 3.12 & 5.34 & \\
\hline
\end{tabular}

Note. $-y=A \cdot \ln x+B$; where: $y$ is the mechanical property (compressive or flexural strength) value $(\mathrm{MPa}) ; A$ and $B$ are constants; and $x$ is mortar age

Table 5. MANOVA values for mechanical strength

\begin{tabular}{|l|c|c|c|c|c|c|}
\hline \multirow{2}{*}{$\begin{array}{l}\text { Source of } \\
\text { variation }\end{array}$} & \multicolumn{3}{|c|}{ Compressive strength } & \multicolumn{3}{c|}{ Flexural strength } \\
\cline { 2 - 7 } & $\begin{array}{c}\text { Type III sum } \\
\text { of squares }\end{array}$ & p-value & CF (\%) & $\begin{array}{c}\text { Type III sum } \\
\text { of squares }\end{array}$ & p-value & CF (\%) \\
\hline Corrected model & 41845.16 a) & 0.00 & - & 551,59 b) & 0.00 & - \\
\hline Intercept & 741415.71 & 0.00 & - & 15741.65 & 0.00 & - \\
\hline Age & 39756.73 & 0.00 & 95.42 & 453.14 & 0.00 & 90.25 \\
\hline $\begin{array}{l}\text { Percentage of the } \\
\text { waste (PW) }\end{array}$ & 1157.18 & 0.00 & 2.78 & 10.02 & 0.00 & 2.00 \\
\hline Waste & 15.01 & 0.06 & 0.04 & 1.33 & 0.05 & 0.27 \\
\hline Age * PW & 159.46 & 0.00 & 0.38 & 5.45 & 0.00 & 1.09 \\
\hline Age * Waste & 52.27 & 0.03 & 0.13 & 10.68 & 0.00 & 2.13 \\
\hline PW * Waste & 19.09 & 0.03 & 0.05 & 0.92 & 0.02 & 0.18 \\
\hline Age * PW * Waste & 69.61 & 0.00 & 0.17 & 2.02 & 0.06 & 0.40 \\
\hline Error & 434.22 & - & - & 18.52 & - & - \\
\hline Corrected total & 41663.57 & - & - & 502.09 & - & - \\
\hline \multicolumn{2}{|c|}{ Note. - CF: contribution of factor; a) $R^{2}=0.991$ (adjusted $R^{2}=0.989$ ); b) $R^{2}=0.968$ (adjusted } \\
\hline
\end{tabular}

Table 6. HSD multiple range groups by age, and percentage and type of waste: compressive strength 


\begin{tabular}{|c|c|c|c|c|c|c|c|c|}
\hline \multicolumn{9}{|c|}{ Compressive strength } \\
\hline \multirow{2}{*}{ 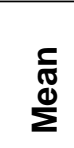 } & \multirow[b]{2}{*}{ Factor } & \multirow[b]{2}{*}{ Group } & \multicolumn{6}{|c|}{ Curing age (d) } \\
\hline & & & 2 & 7 & 28 & 90 & 180 & 365 \\
\hline \multirow[t]{3}{*}{$\uparrow+$} & \multirow{3}{*}{ 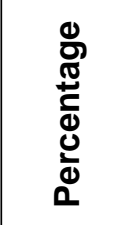 } & 1 & 0 & 0 & 0 & $0>10$ & 10 & $10>20$ \\
\hline & & 2 & 10 & 10 & 10 & 20 & $0>20$ & 0 \\
\hline & & 3 & 20 & 20 & 20 & - & - & - \\
\hline \multirow[t]{2}{*}{$\uparrow^{+}$} & \multirow{2}{*}{ 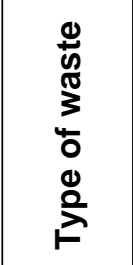 } & 1 & so & so & so & so & $\begin{array}{c}\mathrm{S} 1>\mathrm{S} 2 \\
>\mathrm{S} 3>\mathrm{S} 0\end{array}$ & $\begin{array}{c}\mathrm{S} 1>\mathrm{S} 2 \\
>\mathrm{S} 3\end{array}$ \\
\hline & & 2 & $\begin{array}{c}\mathrm{S} 1>\mathrm{S} 3 \\
>\mathrm{S} 2\end{array}$ & $\begin{array}{c}\mathrm{S} 1>\mathrm{S} 3 \\
>\mathrm{S} 2\end{array}$ & $\begin{array}{c}\mathrm{S} 3>\mathrm{S} 2 \\
>\mathrm{S} 1\end{array}$ & $\begin{array}{c}\mathrm{S} 2>\mathrm{S} 1 \\
>\mathrm{S} 3\end{array}$ & - & so \\
\hline
\end{tabular}

Table 7. HSD multiple range groups by age, and percentage and type of waste: flexural strength

\begin{tabular}{|c|c|c|c|c|c|c|c|c|}
\hline \multicolumn{9}{|c|}{ Flexural strength } \\
\hline \multirow{2}{*}{ 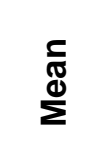 } & \multirow[b]{2}{*}{ Factor } & \multirow[b]{2}{*}{ Group } & \multicolumn{6}{|c|}{ Curing age (d) } \\
\hline & & & 2 & 7 & 28 & 90 & 180 & 365 \\
\hline \multirow[t]{3}{*}{$\uparrow+$} & \multirow{3}{*}{ 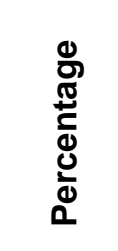 } & 1 & 0 & 0 & 0 & $\begin{array}{c}0>10> \\
20\end{array}$ & 0 & $\begin{array}{c}10>20> \\
0\end{array}$ \\
\hline & & 2 & 10 & 10 & 10 & - & $10>20$ & - \\
\hline & & 3 & 20 & 20 & 20 & - & - & - \\
\hline \multirow[t]{3}{*}{$\uparrow^{+}$} & \multirow{3}{*}{ 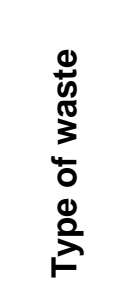 } & 1 & So & so & $\mathrm{S} 0>\mathrm{S} 2$ & $\begin{array}{c}\mathrm{S} 2>\mathrm{S} 1> \\
\text { S0 }\end{array}$ & $\mathrm{S} 1>\mathrm{S} 0$ & $\begin{array}{c}\mathrm{S} 1>\mathrm{S} 2> \\
\mathrm{S} 3>\mathrm{S} 0\end{array}$ \\
\hline & & 2 & S1 & S1 & S1>S3 & $\begin{array}{c}\mathrm{S} 1>\mathrm{S} 0 \\
>\mathrm{S} 3\end{array}$ & $\begin{array}{c}\mathrm{S} 2> \\
\mathrm{S} 3\end{array}$ & - \\
\hline & & 3 & S3> S2 & $S 3>S 2$ & - & - & - & - \\
\hline
\end{tabular}

Table 8. Total porosity and mean pore diameter in $7 \mathrm{~d}, 90 \mathrm{~d}$ and $365 \mathrm{~d}$ mortars 


\begin{tabular}{|c|c|c|c|c|c|c|}
\hline \multirow{2}{*}{ Mortar } & \multicolumn{3}{|c|}{ Total porosity (vol.\%) } & \multicolumn{3}{|c|}{ Mean pore diameter $(\mu \mathrm{m})$} \\
\hline & $7 \mathrm{~d}$ & $90 \mathrm{~d}$ & $365 d$ & $7 d$ & $90 \mathrm{~d}$ & $365 d$ \\
\hline OPC & 12.60 & 10.36 & 10.20 & 0.087 & 0.072 & 0.065 \\
\hline OPC+10S1 & $\begin{array}{l}12.67 \\
(+0.57)\end{array}$ & $\begin{array}{c}10.69 \\
(+3.15)\end{array}$ & $\begin{array}{c}10.22 \\
(+0.16)\end{array}$ & $\begin{array}{l}0.084 \\
(-3.79)\end{array}$ & $\begin{array}{l}0.070 \\
(-1.96)\end{array}$ & $\begin{array}{l}0.059 \\
(-9.40)\end{array}$ \\
\hline OPC+20S1 & $\begin{array}{c}14.40 \\
(+14.27)\end{array}$ & $\begin{array}{c}11.77 \\
(+13.62)\end{array}$ & $\begin{array}{c}11.47 \\
(+12.39)\end{array}$ & $\begin{array}{c}0.078 \\
(-10.10)\end{array}$ & $\begin{array}{c}0.064 \\
(-10.75)\end{array}$ & $\begin{array}{c}0.050 \\
(-22.34)\end{array}$ \\
\hline OPC+10S2 & $\begin{array}{l}13.07 \\
(+3.74)\end{array}$ & $\begin{array}{c}11.49 \\
(+10.90)\end{array}$ & $\begin{array}{l}10.44 \\
(+2.30)\end{array}$ & $\begin{array}{c}0.095 \\
(+9.30)\end{array}$ & $\begin{array}{l}0.066 \\
(-7.54)\end{array}$ & $\begin{array}{c}0.044 \\
(-32.20)\end{array}$ \\
\hline OPC+20S2 & $\begin{array}{c}13.58 \\
(+7.80)\end{array}$ & $\begin{array}{c}12.49 \\
(+20.58)\end{array}$ & $\begin{array}{c}11.57 \\
(+13.35)\end{array}$ & $\begin{array}{l}0.080 \\
(-8.61)\end{array}$ & $\begin{array}{c}0.064 \\
(-11.31)\end{array}$ & $\begin{array}{c}0.036 \\
(-44.22)\end{array}$ \\
\hline OPC+10S3 & $\begin{array}{c}13.88 \\
(+10.18)\end{array}$ & $\begin{array}{c}11.27 \\
(+8.75)\end{array}$ & $\begin{array}{c}10.32 \\
(+1.16)\end{array}$ & $\begin{array}{l}0.086 \\
(-0.92)\end{array}$ & $\begin{array}{l}0.071 \\
(-1.12)\end{array}$ & $\begin{array}{c}0.053 \\
(-18.95)\end{array}$ \\
\hline $\mathrm{OPC}+20 \mathrm{S3}$ & $\begin{array}{c}13.25 \\
(+5.12)\end{array}$ & $\begin{array}{c}11.79 \\
(+13.74)\end{array}$ & $\begin{array}{c}11.33 \\
(+11.04)\end{array}$ & $\begin{array}{l}0.087 \\
(-0.57)\end{array}$ & $\begin{array}{c}0.062 \\
(-13.55)\end{array}$ & $\begin{array}{c}0.037 \\
(-43.76)\end{array}$ \\
\hline \multicolumn{7}{|c|}{ Note. -- in brackets, percentage variation relative to OPC } \\
\hline
\end{tabular}

Table 9. Values used to calculate the energy consumed

\begin{tabular}{|l|c|c|}
\hline \multirow{2}{*}{\multicolumn{1}{|c|}{ Process }} & Cement & Bnergy consumed [ref.] \\
\cline { 2 - 3 } & BBA (S1, S2 y S3) \\
\hline Manufacture & $E_{\text {cement }}^{\text {process }}=1039 \mathrm{~kW} \cdot \mathrm{h} / \mathrm{t}[70]$ & $E_{B B A}^{\text {process }}=0 \mathrm{~kW} \cdot \mathrm{h} / \mathrm{t}^{*}$ \\
\hline Grinding & $E_{\text {cement }}^{\text {grinding }}=50 \mathrm{~kW} \cdot \mathrm{h} / \mathrm{t}[43]$ & $E_{B B A}^{\text {grinding }}=30 \mathrm{~kW} \cdot \mathrm{h} / \mathrm{t}$ \\
\hline \multicolumn{2}{|c|}{ Note. - ${ }^{*} B B A$ is not thermally treated } \\
\hline
\end{tabular}

